\title{
Title: Informing behaviour change intervention design using Bayesian meta- analysis: physical activity in heart failure
}

\section{Authors:}

A. Marat

1. Health Services Research and Management, School of Health Sciences, City, University of London, Northampton Square, London, UK, EC1V OHB.

2. School of Pharmacy. Department of Practice and Policy, Centre for Behavioural Medicine, UCL, BMA House, Tavistock Square, London, UK, WC1H 9JP.

This research was conducted in the absence of any commercial or financial relationships that could be construed as a potential conflict of interest.

\section{Taylor}

1. Department of Psychology, University of Surrey, Guildford, UK, GU2 7XH.

This research was conducted in the absence of any commercial or financial relationships that could be construed as a potential conflict of interest.

\section{B. Volkmer}

1. Health Services Research and Management, School of Health Sciences, City, University of London, Northampton Square, London, UK, EC1V OHB.

2. School of Population Health \& Environmental Sciences, Faculty of Life Sciences and Medicine, King's College London, 2nd Floor, Addison House, Guy's Campus, London, UK, SE1 1UL.

This research was conducted in the absence of any commercial or financial relationships that could be construed as a potential conflict of interest.

\section{N. Ahmed}

1. Health Services Research and Management, School of Health Sciences, City, University of London, Northampton Square, London, UK, EC1V 0HB.

This research was conducted in the absence of any commercial or financial relationships that could be construed as a potential conflict of interest.

\section{A.M. Chater}

1. Institute for Sport and Physical Activity Research (ISPAR), Centre for Health, Wellbeing and Behaviour Change, University of Bedfordshire, Bedford Campus, Polhill Avenue, Bedford, UK, MK41 9EA.

This research was conducted in the absence of any commercial or financial relationships that could be construed as a potential conflict of interest.

\section{T. Fteropoulli}

1. Health Services Research and Management, School of Health Sciences, City, University of London, Northampton Square, London, UK, EC1V 0HB 2. Medical School. University of Cyprus, Nicosia, NOTE: This Cyprus. 
medRxiv preprint doi: https://doi.org/10.1101/2021.09.05.21262643; this version posted September 8, 2021. The copyright holder for this preprint (which was not certified by peer review) is the author/funder, who has granted medRxiv a license to display the preprint in It is made available under a CC-BY-NC 4.0 International license.

This research was conducted in the absence of any commercial or financial relationships that could be construed as a potential conflict of interest.

\section{Protocol:}

The review's protocol was registered on PROSPERO: CRD42021232048

\section{Funding:}

This research was supported by a PhD studentship awarded by City University London.

\section{Availability of data, code and other materials:}

https://github.com/AliyaAM/bayes_meta 
medRxiv preprint doi: https://doi.org/10.1101/2021.09.05.21262643; this version posted September 8, 2021. The copyright holder for this preprint (which was not certified by peer review) is the author/funder, who has granted medRxiv a license to display the preprint in It is made available under a CC-BY-NC 4.0 International license .

\section{Abstract}

Embracing the Bayesian approach, we aimed to synthesise evidence regarding barriers and enablers to physical activity in HF in a way that can inform behaviour change intervention development. This approach helps in concluding on the uncertainty in the evidence and facilitates the synthesis of qualitative and quantitative evidence. Qualitative and observational studies investigating barriers and enablers to physical activity in adults diagnosed with HF were included in a Bayesian metaanalysis. Evidence from three qualitative and 16 quantitative studies was synthesised. Qualitative evidence was annotated using Theoretical Domains Framework and represented as a prior distribution using an expert elicitation task. The maximum a posteriori probability (MAP) and Credible Intervals $(C r I)$ was calculated as a summary statistic for the probability distribution of physical activity conditioned on each determinant, according to qualitative evidence alone and qualitative and quantitative evidence combined. Evidence concerning the modifiable barriers and enablers is highly uncertain: social support $(M A P=0.11, C r I:[0.08 ; 0.13])$, negative attitude $(M A P=0.22, C r I:[0.17 ; 0.27])$, positive attitude ( $M A P=0.27, C r I:[0.23 ; 0.31]$ ), self-efficacy $(M A P=0.31, C r I:[0.29 ; 0.33])$, symptom distress $(M A P=021, C r I:[0.18 ; 0.24])$. The contextual barriers - low, moderate and high uncertainty respectively are age $(M A P=0.22, C r I:[0.22 ; 0.23])$, low Left Ventricular Ejection Fraction $(M A P=0.20, C r I:[0.19 ; 0.22])$, and depression $(M A P=0.14, \operatorname{Cr}:[0.12 ; 0.16])$. This work extends the limited research on the modifiable barriers and enablers for physical activity by individuals living with HF.

Keywords: physical activity, heart failure, Bayesian meta-analysis, behaviour change, barriers and enablers, Theoretical Domains Framework. 
medRxiv preprint doi: https://doi.org/10.1101/2021.09.05.21262643; this version posted September 8, 2021. The copyright holder for this preprint (which was not certified by peer review) is the author/funder, who has granted medRxiv a license to display the preprint in It is made available under a CC-BY-NC 4.0 International license .

\section{Word count: 5949 words, 15 pages.}

Excluding abstract, figures, tables, references

\section{Three tables.}

\section{Six figures.}

\section{Supplements:}

1. Detailed Inclusion criteria. The scope of the review: pi(e)cos and spider

2. Search strategy.

3. Statistical analysis.

4. The citations for the included studies.

5. The citations for the studies that were excluded but appear to meet the inclusion criteria (with reasons for exclusion)

6. Studies that appear to meet the inclusion but were excluded (with the reasons for exclusion).

7. Physical activity assessment across studies.

8. Individual studies risk of bias.

9. Checklist: criteria for evaluating studies employing Bayesian statistics (1).

10. PRISMA checklist: https://prisma.shinyapps.io/checklist/. 
medRxiv preprint doi: https://doi.org/10.1101/2021.09.05.21262643; this version posted September 8,2021 . The copyright holder for this preprint (which was not certified by peer review) is the author/funder, who has granted medRxiv a license to display the preprint in

It is made available under a CC-BY-NC 4.0 International license.

\section{Introduction}

Heart Failure (HF) is a complex clinical syndrome of symptoms that suggest reduced efficiency with which the heart pumps blood around the body (2). It is a prevalent condition worldwide (3) and in the UK (2) affecting $2 \%$ of the population.

Physical activity is associated with improved quality of life (4-7), reduced hospitalisation (6) and increased longevity $(8,9)$ in individuals living with HF. Therefore, regular physical activity is a key component of recommended treatment (10). While the minimal clinically important difference in physical activity levels in HF is not known $(11,12)$, the recommendation for older adults, in general, is to perform a minimum of 75 150 minutes per week of moderate-intensity aerobic physical activity and engage in functional balance and muscle strength training at a moderate intensity at least three days a week (13).

A structured form of physical activity - exercise -- is included in cardiac rehabilitation (CR) and is offered to newly diagnosed HF patients (2). However, uptake of CR programmes is less than $1 \%$ among individuals diagnosed with HF (14). Levels of everyday physical activity in HF are also low $(15,16)$, partially due to the many challenges individuals with HF face in initiating and maintaining a physically active lifestyle, as proposed by the European Society of Cardiology (17). Understanding how best to improve physical activity in individuals living with HF is warranted.

There is emerging evidence that behaviour change interventions (18) and interventions based on a behaviour change theory (19) addressing physical activity are potentially promising for promoting physical activity in individuals living with HF. However, only a small number of theories have been applied in the development of existing interventions to improve physical activity in HF (18). These were Motivational Interviewing (20); a combination of Self-Determination Theory, Common-Sense Model, and Control Theory (21); Cognitive Behavioural Therapy (22); Social Cognitive Theory alone $(23,24)$; and in combination with the Transtheoretical Model of Change (25). The extent to which a theory informed interventions was limited (18).

Guidelines for developing behaviour change interventions recognise that the modifiable and contextual barriers and enablers need to be systematically identified and described to inform intervention design (26-31). Knowledge about relevant determinants increases the intervention's chances to be effective and conserves research effort and resources $(26,29)$. Systematically identified evidence concerning modifiable and contextual barriers and enablers can guide theory choice and therefore inform behaviour change intervention design. 
medRxiv preprint doi: https://doi.org/10.1101/2021.09.05.21262643; this version posted September 8,2021 . The copyright holder for this preprint (which was not certified by peer review) is the author/funder, who has granted medRxiv a license to display the preprint in It is made available under a CC-BY-NC 4.0 International license.

However, the factors influencing physical activity participation in individuals living with HF are not well understood. A systematic review of qualitative studies found a lack of research on individual accounts of barriers and enablers to physical activity in individuals living with HF (19). The review reported sparse summaries about physical activity extracted from the studies that elucidated beliefs and personal accounts of living with HF in general, including physical activity only as one of many themes (19). The following enablers: knowledge of risks and benefits associated with physical activity (e.g., reduced mortality and morbidity, and improved quality of life); confidence in one's ability to engage in physical activity; anticipated outcomes of physical activity; and social support, as well as a barrier such as weather, were previously identified in a systematic narrative review (19). However, these barriers and enablers have not been confirmed in quantitative studies. The review highlighted the need to explore further what influences physical activity in HF (19).

A recent paper called for the adoption of Bayesian statistics in Health Psychology research $(1,32-34)$, which might be useful in understanding the contextual and modifiable determinants influencing physical activity in HF. The Bayesian approach views evidence synthesis as a decision-making process (35); new evidence is considered in light of existing evidence, beliefs, and practices. Beliefs are often presented in the form of qualitative research. Qualitative research is readily available from research studies on health and health management; however, its findings are not utilised in healthcare decision-making and policy development (35). Qualitative research provides rich data, but the required formal systematic evaluation impedes the inclusion of qualitative evidence in decision-making and policy development (35). This makes it difficult for qualitative evidence to inform policy-making (35). It is also recommended to account for stakeholders' needs - the needs of those living with HF in this instance - in research concerning intervention development (26). While Bayesian methods provide an opportunity to incorporate qualitative evidence in decisions about health management (36). Therefore, Bayesian methods are useful when evidence from diverse sources needs to be synthesised.

However, to perform Bayesian synthesis, qualitative research should be formally and systematically catalogued before it can be integrated with quantitative findings, which is often not straightforward (35). Theoretical Domains Framework (37) is a tool developed through an international collaborative effort that systematically describes domains and constructs that may influence behaviour under investigation. The identified physical activity barriers and enablers in HF were categorised in accordance with the TDF. In addition, a model developed from a systematic synthesis of behaviour change frameworks - COM-B (38) was used to inform future behaviour change interventions targeting physical activity in HF. In particular, following the consensus on the link between barriers and enablers and the strategies (39), several strategies (i.e., behaviour change techniques, BCTTv1 (40)) that are likely to amplify the identified relevant enablers or tackle the barriers were proposed. 
medRxiv preprint doi: https://doi.org/10.1101/2021.09.05.21262643; this version posted September 8,2021 . The copyright holder for this preprint (which was not certified by peer review) is the author/funder, who has granted medRxiv a license to display the preprint in

It is made available under a CC-BY-NC 4.0 International license.

\section{Objectives}

The present review and meta-analysis aim to systematically integrate qualitative and quantitative evidence on the clinical, environmental, and psychosocial barriers and enablers influencing physical activity in those living with HF. The secondary aim, which is a response to the recent call $(1,32-34)$, is to apply the Bayesian approach in synthesising evidence regarding barriers and enablers to physical activity in HF in a way that can inform behaviour change intervention development.

\section{Method}

The meta-analysis was implemented adhering to guidance on conducting systematic reviews and metaanalyses of observational studies of aetiology, COSMOS-E (41). The review is reported following PRISMA 2020 guidelines. The review's protocol was registered on PROSPERO: CRD42021232048.

\section{Eligibility criteria}

Qualitative and observational studies investigating any clinical, environmental, social, or psychological barriers and enablers to physical activity in adults diagnosed with HF were included in this review (supplement $1)$.

\section{Information sources}

A total of 14 online databases were searched from inception to 05 January 2020 (Embase, Global Health, HMIC Health Management Information Consortium, MEDLINE; PsychINFO; CINAHL; Health policy reference centre; PsychARITCLES; PubMed; The Cochrane Library; Academic search complete, Pedro). The reference lists of the obtained articles included at full-text screening were hand searched for relevant studies meeting the inclusion criteria. In addition, ClinicalTrial.gov was searched for observational studies but yielded no results.

\section{Search strategy}

The MeSH terms and keywords describing the Population of interest (i.e. HF and nine synonyms combined using a Boolean operator 'OR') and Outcome of interest (i.e. physical activity and 21 synonyms combined using a Boolean operator 'OR') were combined using a Boolean operator 'AND' (supplement 2). The initial search yielded 11,678 hits $(11,678)$. For practical reasons, the search results were further restricted to peer-reviewed articles in English.

\section{Selection process}

Two reviewers (AA and LT) independently screened abstracts and selected articles meeting the criteria for full-text screening in Rayyan. Qualitative studies meeting the eligibility criteria informed the prior elicitation task (i.e. appraisal by a panel of experts). Quantitative studies were included in the frequentist metaanalysis. The results of the elicitation task and the frequentist meta-analysis were combined in the Bayesian meta-analysis. 
medRxiv preprint doi: https://doi.org/10.1101/2021.09.05.21262643; this version posted September 8,2021 . The copyright holder for this preprint (which was not certified by peer review) is the author/funder, who has granted medRxiv a license to display the preprint in It is made available under a CC-BY-NC 4.0 International license.

\section{Data collection process}

Two reviewers (AA and LT) independently extracted relevant data items from the reports of the included studies.

\section{Data items}

The Strengthening the Reporting of Observational Studies in Epidemiology items, STROBE (42) were utilised to design the data extraction form (supplement 3).

\section{Study risk of bias assessment}

Two reviewers (AA and LT) independently assessed the study-level risk of bias present in the included quantitative studies. The following sources of bias were considered: selective reporting, participant selection, missing data (including non-respondents and dropouts), confounding (measured and unmeasured confounds; time-varying confounds in cohort studies), and outcome definition and measurement (i.e. information bias) (41). Due to the lack of a comprehensive risk of bias tool designed specifically for observational studies (43), three instruments were used jointly: the Appraisal tool for Cross-Sectional Studies (AXIS), Working Group Item Bank (WGIB), and Risk Of Bias In Non-randomised Studies - of Interventions (ROBIN-I; (43-45). The ROBIN-I item concerning the randomisation procedure was omitted; an "intervention" was substituted with "exposure".

\section{Summary measures}

Standardised mean differences (SMD) were estimated to describe the impact of exposure on the levels of physical activity as follows: (a) cross-sectional assessment of the differences between the group presenting with a characteristic and the group not presenting with a characteristic (e.g. female $=1$; male $=0$ ); (b) prepost-assessment of physical activity in a cohort study before and after an event of interest (e.g. SMD between physical activity outcome before surgery and after surgery); cross-sectional assessment of differences between exercise compliant and non-compliant participants on a range of continuous variables (e.g. SMD in selfefficacy between compliers and non-compliers). The cut-off points used to define exercise compliance were noted for each study. In studies reporting categorical variables, the two upper bound categories and one lower bound category were used as an effect size estimate and integrated into the frequentist meta-analysis. The r-z transformation was applied in the frequentist meta-analysis of coefficients to mitigate heterogeneity in measurements across studies. The Hartung-Knapp (Sidik-Jonkman) adjustment was made for the evaluation to mitigate small sample size bias (46).

For the Bayesian meta-analysis, the maximum a posteriori probability (MAP) estimate and credible Intervals were calculated as a summary statistic for the probability distribution of physical activity conditioned on each determinant, according to qualitative evidence alone (i.e., prior) and qualitative and quantitative evidence combined (i.e., posterior). 
medRxiv preprint doi: https://doi.org/10.1101/2021.09.05.21262643; this version posted September 8,2021 . The copyright holder for this preprint (which was not certified by peer review) is the author/funder, who has granted medRxiv a license to display the preprint in It is made available under a CC-BY-NC 4.0 International license.

\section{Synthesis methods}

Bayesian meta-analysis (36) was conducted in R (Figure 1). Bayesian updating was performed to obtain the probability of physical activity in HF conditioned on each barrier or enabler separately (35). Detailed statistical analysis is reported in supplement 3 . When the barrier/enabler was described in both qualitative and quantitative studies, then Bayesian updating was performed twice, Procedure 1 (Figure 2). First, evidence for physical activity in the general HF population (i.e., hyperprior) described in Jaarsma et al. (15) was updated with evidence concerning a barrier/enabler from qualitative studies (i.e., prior). The qualitative evidence was synthesised using the Theoretical Domains Framework (37). Then, a prior elicitation task was developed to capture experts' $(\mathrm{N}=6)$ beliefs about the probability distribution for physical activity conditioned on the constructs identified relevant in qualitative evidence (i.e. informative prior). A prior elicitation task is described in supplement 3. This then was updated with quantitative evidence concerning this barrier/enabler (i.e., likelihood). When solely qualitative evidence was available, only the first step was completed (Procedure 2). Likewise, when a barrier or enabler was assessed solely in quantitative studies, only the second step was performed (Procedure 3).

\section{Applying findings to intervention development}

The identified modifiable barriers and enablers were mapped onto TDF (47) and COM-B (38). Accordingly, several corresponding strategies (i.e., behaviour change techniques, BCTTv1 (40)) that are likely to amplify these enablers or tackle the barriers were proposed following the consensus on the link between barriers and enablers and the strategies (39).

\section{Reporting bias assessment}

To assess the impact of the qualitative evidence on the findings of this meta-analysis, we performed sensitivity analysis by excluding the qualitative evidence.

\section{Certainty assessment}

The uncertainty in the evidence was expressed using Credible Intervals (CrI) and visually, in the form of the distribution dispersion, for each barrier or enabler separately.

\section{Results}

\section{Study selection}

The search results are summarised in Figure 3. A total of 9026 titles and abstracts and 80 full-text articles were screened. Nineteen studies cited in supplement $4(\mathrm{~N}=2739)$ were included in the review, Figure 3. Studies that might appear to meet the inclusion criteria but were excluded, as well as the reasons for exclusion, are reported in supplement 5. 
medRxiv preprint doi: https://doi.org/10.1101/2021.09.05.21262643; this version posted September 8, 2021. The copyright holder for this preprint (which was not certified by peer review) is the author/funder, who has granted medRxiv a license to display the preprint in It is made available under a CC-BY-NC 4.0 International license.

\section{Study characteristics}

Studies were conducted in the United States of America $(n=8)$, United Kingdom $(n=3)$, Netherlands $(n=2)$, Sweden $(n=2)$, Australia $(n=1)$, Germany $(n=1)$, Taiwan $(n=1)$, and South Korea $(n=1)$. The majority of the included studies were of a cross-sectional design $(n=7$, Table 1$)$. The average sample size for quantitative and empirical qualitative studies were 150 and 17, respectively. Physical activity operationalisation and assessment methods are reported in supplement 6. The mean age of the participants was 63.44 years old (SD $=8.39$, median $=62.15, I Q R:[59.5 ; 68])$. The Left Ventricular Ejection Fraction (LVEF, \%) was moderately low $($ mean $=34.52 \%, \mathrm{SD}=9 \%$ ). Overall, the majority of samples in the included studies were homogeneous.

\section{Risk of bias in studies}

The risk of bias across the included studies is reported in Figure 4. The low overall risk of bias was present in 12 (75\%) studies, moderate - in three (18.75\%) studies (Alosco et al., 2012; Chien et al., 2014; Corvera-Tindel et al., 2004), and serious - in one study (Evangelista et al., 2001). One (6.25\%) study was exposed to a serious risk of reporting bias, as only statistically significant results were reported (Evangelista et al., 2001). A total of nine (56.25\%) studies did not have a pre-registered protocol, and therefore no information on the bias in the selection of reported results was available. The measurement bias caused by the dichotomisation of the age variable was present in two (12.50\%) studies (Evangelista et al., 2001; Evangelista et al., 2003). Participant selection bias was present in one (6.25\%) study (Klompstra et al., 2018). Out of four prospective $(25 \%)$ studies, only one $(6.25 \%)$ controlled for time-confounding variables by matching participants in exposed and unexposed groups (Moreno-Suarez et al., 2019). Only three (18.75\%) studies were exposed to low risk of bias attributed to confounding: two matched participants (i.e., by gender and severity of the disease) when assessing differences in exposed and unexposed groups (Evangelista et al., 2003; MorenoSoarez et al., 2019), and one measured appropriate confounding variables (Klompstra et al., 2018). The studylevel risk of bias assessment is reported in supplement 7.

\section{Results of synthesis}

\section{Qualitative evidence}

The qualitative evidence synthesis and results are detailed in supplement 3. One theme, 'Losing one's social role in daily life', was annotated as Social, Professional Role and Identity. It captured how the loss of participants' social network and position in society negatively influenced their engagement in physical activity (Pihl et al., 2011). A theme, 'Need of finding practical solutions in daily life' (Pihl et al. 2011), was classified into Behavioural Regulation and summarised the need for effective problem solving that enabled integration of physical activity in daily life with ease (supplement 3). One study (Tierney et al., 2011b) identified the relevance of the following domains: Environmental Context \& Resources, Social Influences, Knowledge (supplement 3). Overall, the following barriers and enablers influencing physical activity performance by individuals living with HF were found uniquely in qualitative evidence: Social, Professional Role and Identity, Environmental Context and Resources, Behavioural Regulation, according to three included qualitative studies (Tierney et al., 2011a; Tierney et al., 2011b, Pihl et al., 2011). 
medRxiv preprint doi: https://doi.org/10.1101/2021.09.05.21262643; this version posted September 8,2021 . The copyright holder for this preprint (which was not certified by peer review) is the author/funder, who has granted medRxiv a license to display the preprint in

It is made available under a CC-BY-NC 4.0 International license.

The determinants that were reported by both qualitative and quantitative studies were: age, perceived symptoms of HF, functioning, comorbidity, negative attitude, positive attitude, social support, and selfefficacy. In qualitative studies, the influence of ageing processes was described as 'Changing Soma' (Beliefs about CapabilitieOs (Tierney et al., 2011b). Perceived symptoms of HF were described as 'Fluctuating health' (Beliefs about Consequences) which impacted physical activity participation (Tierney et al., 2011b). Positive attitude toward physical activity in qualitative studies described as 'Mental Outlook' (Belief about Consequence) (Tierney et al., 2011b), and negative attitude toward physical activity in the included qualitative study described as 'Negative emotional responses', (Emotion/Optimism (Tierney et al., 2011a), social support was described as 'Interpersonal Influences' (Social Influences) (Tierney et al., 2011a), and self-efficacy as 'Not believing in one's ability' (Beliefs about Capabilities_(Pihl et al., 2011). These qualitative findings informed the expert elicitation task (supplement 3).

\section{Frequentist meta-analysis results}

The findings, the number of studies assessing the identified constructs, and the assessment method of both physical activity and the construct are reported in Table 2 . In the meta-analysis including univariate associations ( $r-z$ coefficient, $95 \% C I$ ), the following determinants were significantly and negatively correlated with physical activity levels: age, comorbidity, depression, and HF-diagnosis duration (Table 2). Positive attitude toward physical activity, physical functioning, 6-minute walking test, perceived symptoms, and selfefficacy were significantly and positively correlated with physical activity (Table 2). In the meta-analysis of differences $(S M D, 95 \% C I)$, the following barriers to physical activity were identified: being employed, Left Atrial Volume index (LAV; 1/m2), perceiving higher social support in managing HF, and living with a partner (Table 2).

Individuals living with HF who adhered to the recommendations to walk for at least 225 minutes of per week had a significantly larger mean PeakV02, mean HF diagnosis duration (years), and comorbidity score (Charlston Comorbidity Index, CCI), than those who did not (Table 2). Individuals with low levels of physical activity (average daily accelerometry units $=5077 \pm 1154$ ) had significantly worse renal function (estimated glomerular filtration rate, eGFR, $\mathrm{ml} / \mathrm{min}$ ), higher doppler estimated filling pressure, and reduced Quality of Life (KCCQ scale, Table 2) than those with high levels (average daily accelerometry units $=15287 \pm 4821$ ). Individuals who had a Left Ventricular Assist Device (LVAD) implanted had significantly higher daily energy expenditure than those who did not have an LVAD $(404.1 \pm 169.1 \mathrm{kcal} / \mathrm{d}-1$ for the LVAD group and $222.5 \pm$ $163.4 \mathrm{kcal} / \mathrm{d})$, Table 2.

\section{Bayesian meta-analysis results}

The relative probability of physical activity conditioned on the identified barriers and enablers is described in Figure 5 and Figure 6.

Contextual barriers

the Bayesian meta-analysis identified the following contextual barriers - with low, moderate, and high uncertainty, respectively - age (MAP $=0.22$, CrI: [0.22;0.23]), low Left Ventricular Ejection Fraction (MAP 
medRxiv preprint doi: https://doi.org/10.1101/2021.09.05.21262643; this version posted September 8,2021 . The copyright holder for this preprint (which was not certified by peer review) is the author/funder, who has granted medRxiv a license to display the preprint in

It is made available under a CC-BY-NC 4.0 International license.

$=0.20, \mathrm{CrI}:[0.19 ; 0.22])$, and depression $(\mathrm{MAP}=0.14, \mathrm{CrI}:[0.12 ; 0.16])$. Older age $(>70)$ and low LVEF $(<35 \%)$ reduced the probability for physical activity in $\mathrm{HF}, M A P P_{\mathrm{PA} \mid \mathrm{HF}, \mathrm{Age}>70}=0.221$ and $M A P P_{\mathrm{PA} \mid \mathrm{HF}, \mathrm{LVEF}<35 \%}=0.202$, respectively. Depression, measured using HADS-D CES-D and PROMIS-29, reduced the probability for physical activity in $\mathrm{HF}$ by twofold $\left(M A P_{\mathrm{PA} \mid \mathrm{HF} \text {, Depression }}=0.140\right.$ vs $\left.M A P_{\mathrm{PA} \mid \mathrm{HF}}=0.320\right)$. The probability distribution for physical activity conditioned on other barriers and enablers identified in quantitative evidence was highly uncertain (Figure 5). High pro-b-type natriuretic peptide, pro-BNP and low LAV reduced the probability for physical activity by twofold, $M A P=0.142$ and $M A P=0.150$, respectively. Having an implantable device (LVAD, MAP $=0.395)$, high doppler estimated filling pressure $(M A P=0.403)$, and high 6minute walking test result (meters, $M A P=0.347$ ), as well as a diagnosis of $\mathrm{HFrEF}$ (vs $\mathrm{HFpEF}, M A P=0.399$ ), were identified as enablers of physical activity in HF. However, evidence was highly uncertain (Figure 5).

\section{Modifiable barriers}

Evidence concerning the modifiable barriers and enablers is highly uncertain: social support (MAP = 0.11, CrI: [0.08;0.13]), negative attitude (Emotion/Optimism, MAP = 0.22, CrI: [0.17;0.27]), positive attitude (Belief about Consequence, MAP = 0.27, CrI: [0.23;0.31]), and self-efficacy (MAP=0.31, CrI: [0.29;0.33]), and symptom distress (Emotion, MAP $=021$, CrI: $[0.18 ; 0.24]$ ).

\section{Reporting biases}

\section{Sensitivity analysis results}

The results of the sensitivity analysis are summarised in Figure 6. Qualitative and quantitative evidence concerning the probability of physical activity conditioned on social support (Social Influences) contradicted each other (Figure 6). While social support (Social Influences) in managing HF was elicited as an enabler in qualitative evidence (i.e., expert elicitation task), it was found to reduce the probability for physical activity in a quantitative study (Gallagher et al., 2011), where it was measured using the social support index (high levels of perceived social support vs low levels of perceives social support) developed as part of the study (Gallagher et al., 2011). However, the results concerning other barriers and enablers identified in both sources of evidence (qualitative and quantitative) were not substantially different to each other (Figure 6).

\section{Applying findings to intervention development}

Table 3 reports barriers and enablers identified in qualitative evidence that need to be further investigated in quantitative studies (high uncertainty) and barriers and enablers supported in quantitative evidence with low or moderate uncertainty and the behaviour change strategies that may be useful in addressing them.

\section{Certainty of evidence}

There is relatively low uncertainty (reflected in narrow Credible Intervals $(\mathrm{Cr} I)$ and low dispersion of the probability distribution, Figure 5) in qualitative and quantitative evidence suggesting that older age (>70 years old) is a considerable barrier to physical activity in HF. There is moderate uncertainty in the evidence from quantitative studies suggesting that low LVEF (\%) and depression are both barriers. However, the 
medRxiv preprint doi: https://doi.org/10.1101/2021.09.05.21262643; this version posted September 8,2021 . The copyright holder for this preprint (which was not certified by peer review) is the author/funder, who has granted medRxiv a license to display the preprint in It is made available under a CC-BY-NC 4.0 International license.

evidence concerning other barriers and enablers is highly uncertain (reflected in wide Credible Intervals (CrI) and high dispersion of the probability distribution, Figure 5).

\section{Discussion}

This review aimed to identify, describe, and compare contextual and modifiable barriers and enablers to physical activity in HF using a Bayesian approach. Both qualitative and quantitative studies were included in this review and meta-analysis. This work extends the limited research on the modifiable barriers and enablers for physical activity participation by individuals living with HF. Evidence concerning the modifiable barriers: negative attitude and symptom distress; and enablers: social support, positive attitude, self-efficacy is highly uncertain. The contextual barriers supported by the evidence are age, low Left Ventricular Ejection Fraction, and depression with low, moderate, and high uncertainty, respectively.

\section{Contextual barriers and enablers}

This review identified the following contextual barriers: age, depression, and low LVEF (<30\%). Older age is a barrier to physical activity in HF, as suggested by both qualitative and quantitative evidence. This result further reiterated the finding of a meta-analysis (18) that older adults living with HF need more support to attain higher physical activity levels.

Depression lowered the probability of physical activity as identified by the quantitative evidence. Depression is a large burden in the HF population. It is associated with poor adherence to pharmaceutical treatment (48) and is an independent predictor of morbidity (49). The physiological determinants perpetuating depression in HF include inflammation, blood cell abnormalities, CNS changes and changes in healthprotective behaviours (50). The association between depression, HF, and lack of physical activity is complex. Like any cardiovascular disease, HF is a consequence of low physical activity in clinically depressed individuals (51). More research investigating the mechanism via which depression impacts physical activity in HF is needed.

The review findings concerning employment are in accord with a qualitative semi-structured interview study with a non-clinical sample of adults transitioning to retirement, which found that retirement is perceived as providing opportunities to become physically active (52). On the other hand, authors also reported that this was not always the case, and an individualised approach may be required (52). Similarly, a national survey of 1550 adults aged 60-69 in England in 2007 reported that work commitments and lack of leisure time were major barriers to physical activity (53). Context, social norms surrounding physical activity in older age may impact how physical activity is enacted in older adults who transitioned to retirement $(54,55)$.

The diagnosis of HFrEF and its duration may engender a higher risk of physical inactivity than the diagnosis of HFpEF However, the available evidence is uncertain, and more evidence is needed before drawing any definitive conclusions. Non-cardiovascular comorbidities in HF include Diabetes Mellitus (type 2), chronic 
medRxiv preprint doi: https://doi.org/10.1101/2021.09.05.21262643; this version posted September 8,2021 . The copyright holder for this preprint (which was not certified by peer review) is the author/funder, who has granted medRxiv a license to display the preprint in

It is made available under a CC-BY-NC 4.0 International license.

obstructive pulmonary disease (COPD), and renal dysfunction (56). These comorbidities increase both morbidity and mortality in HF (56). A frequent cardiovascular condition that accompanies HF is atrial fibrillation, AF (57). Another clinical barrier identified by the present review is longer HF duration which is likely to result in deterioration of functionating. Another review investigating barriers and enablers to physical activity post coronary artery bypass graft surgery found a lack of evidence concerning enablers of the behaviour; however, the authors suggested that symptoms like pain and fatigue impede physical activity even three months after the surgery (58). Overall, it is likely that symptoms experienced immediately after recovery and longer HF diagnosis duration, as well as multimorbidity, contribute to limited physical activity levels.

Age, depression and low LVEF (\%) need to be carefully considered in both future cross-sectional studies and randomised-controlled trials evaluating the mechanism of change. Understanding the contextual determinants influencing behaviour is useful in informing the design of quantitative research studies investigating modifiable determinants influencing physical activity (59). Contextual differences (i.e., age, LVEF, and depression) indicate that different approaches to behaviour change interventions for these subgroups that take into account their unique clinical characteristics and align with the European Society of Cardiology (10) and NICE (2) guidelines are required. The review encourages the consideration of these patient characteristics in the intervention design and its tailoring. However, contextual understanding does not provide insights into what can and needs to be changed for these demographic and clinical subgroups to engage in physical activity. This urges research on modifiable barriers and enablers to physical activity in HF in these subgroups.

\section{Modifiable barriers and enablers}

Both qualitative and quantitative evidence included in this meta-analysis suggests that perceived symptoms and negative attitude (Emotion) are relevant barriers. However, the evidence on the modifiable barriers and enablers is highly uncertain. In addition, the evidence concerning social support (Social Influences) is inconclusive when comparing qualitative and quantitative evidence. A quantitative study included in this review assessed differences in physical activity in individuals with high vs low perceived social support in managing their HF and identified that those who perceived more support engaged in physical activity significantly less (Gallagher et al., 2011). On the other hand, qualitative evidence uncovered both positive and negative influences of social support on physical activity levels (Pihl et al., 2011). This included caregivers shielding individuals with HF from any physical activity by assisting in or even overtaking their daily responsibilities. The qualitative evidence identified by this review suggests that activities of daily living, such as climbing stairs, walking, and housekeeping, are vital to individuals living with HF in preserving their physical functioning. However, their family and friends may limit their independence in carrying out these activities (Pihl et al., 2011). There are two likely explanations for this divergence in the evidence. Either quantitative studies require a more nuanced understanding of Social Influences on physical activity in HF, or qualitative research overestimates the impact of Social Influences. Both possibilities should be explored in future research. In comparison, another review of qualitative and quantitative studies on barriers and enablers 
medRxiv preprint doi: https://doi.org/10.1101/2021.09.05.21262643; this version posted September 8,2021 . The copyright holder for this preprint (which was not certified by peer review) is the author/funder, who has granted medRxiv a license to display the preprint in It is made available under a CC-BY-NC 4.0 International license.

relevant to older adults (65-70 years old) and middle-aged adults (50-64 years old) identified that older adults might rely on social influence, social reinforcement and assistance in managing the change in lifestyle to a greater extent than the middle-aged adults (60). Older adults require social support in managing HF and daily life.

Overall, three domains were identified uniquely in qualitative research: Beliefs about Consequences, Environmental Context and Resources and Behavioural Regulation and Social Professional Role and Identity. According to qualitative evidence alone, individuals living with HF are driven by the motivation to achieve the desired outcome, such as improved health (Beliefs about Consequences). According to qualitative research, the local environment that encouraged physical activity (e.g., parks; Environmental Context and Resources) was fundamental for physical activity enactment. Beliefs about pharmaceutical treatment (necessity and concerns and its impact on physical activity; Environmental Context and Resources) and the need to find practical solutions to overcome limitations in physical activity (i.e. problem solving; Behavioural Regulation) played a crucial role in physical activity, according to the qualitative studies included in this review. While the change in perceived social role, described as a loss of social network and position in society brought about as a result of HF, had negative implications for physical activity (Social Professional Role and Identity). However, these were not followed up with a quantitative study to confirm their relevance in a larger sample. This meta-analysis suggests exploring and confirming the role of these barriers and enablers in quantitative research.

\section{Study-level limitations}

Currently, there is no gold standard risk of bias assessment for observational studies (43). Therefore, this review included categories of sources of bias traditionally proposed for assessing study-level bias. These include confounding bias, selection bias, measurement bias, missing data bias, and reporting bias (43). These collectively formed the criteria for evaluating the risk of bias across the included studies. Overall, the majority of the studies (75\%) were exposed to a low risk of bias. The major source of bias in the included studies is confounding, as the majority of observational studies included in the review (81.25\%) did not control for confounding effects when assessing correlates of physical activity.

\section{Strength and limitations of this review}

The Bayesian approach can enable the comparison of the extent to which a barrier or enabler influences behaviour and helps in concluding on the uncertainty in the evidence. It can be used to inform intervention development with stakeholders' accounts using qualitative research. The Bayesian approach facilitates the synthesis of qualitative and quantitative evidence. This method also enables situating the evidence regarding barriers or enablers to behaviour in the context of prior evidence. In this study, the probability for physical activity engagement is conditioned on each barrier or enabler is situated in the context of low levels of physical activity in HF.

The present review synthesised evidence from different sources. The prior elicitation task facilitated this. The results of the expert elicitation task were updated with quantitative evidence. Such Bayesian updating of the probability of physical activity in HF conditioned on each construct summarises both qualitative and 
medRxiv preprint doi: https://doi.org/10.1101/2021.09.05.21262643; this version posted September 8,2021 . The copyright holder for this preprint (which was not certified by peer review) is the author/funder, who has granted medRxiv a license to display the preprint in

It is made available under a CC-BY-NC 4.0 International license.

quantitative evidence. This approach was first implemented by Dixon-Woods and colleagues (35,61). DixonWoods et al. $(35,61)$ advocated for integrating qualitative research in healthcare decision making because it provides valuable insights and places the patient in the heart of care by bringing their perspective into account. However, Roberts et al. (35) highlighted the following shortcoming of using Bayesian meta-analysis. Qualitative research should be formally and systematically catalogued before it can be integrated with quantitative findings, which is often not straightforward. Using the TDF (37) in the present review, we mitigated this limitation.

We have adhered to the criteria for Bayesian research in conducting this review, supplement 8 (1). However, there are three limitations. First, this meta-analysis offered claims about the association, not causality. Second, the prior was elicited using an expert elicitation task with a limited panel of experts. Health psychology researchers appraised qualitative evidence. They then completed a task designed to elicit a prior probability for physical activity conditioned on the constructs identified in the included qualitative studies. While this is an established technique for formalising an informative prior, it is by definition subjective and thus depends strongly on the members of the expert panel (62). In this case, the panel was limited, containing only health psychologists. It would have been beneficial to include other stakeholders such as HF nurses or cardiologists.

Third, while SMD and r-z coefficients were combined appropriately depending on the available data in two different frequentist meta-analyses. For the Bayesian meta-analysis, the available data from each study was converted to a log OR and then pooled in a meta-analysis. This was done so the evidence could be situated in the context of generally low physical activity in HF. An empirical hyperprior was elicited from evidence on physical activity in HF, which was binary - engagement in physical activity (yes/no) among a large sample (15). When performing Bayesian meta-analysis, the choice of a hyperprior is dictated by the objectives and research questions of a study (63-65). In this review, the objective was to compare barriers and enablers in the context of low physical activity in HF. A noninformative prior is much too conservative to be useful for this (66). A noninformative prior would assume that people with HF engage in physical activity as much as any population group, an assumption that is not supported by the available evidence (16). The choice of this empirical hyperprior, while being well-fitted for the objective, resulted in the dichotomisation of the physical activity outcome in the Bayesian meta-analysis (log OR). An alternative would be to obtain continuous data on physical activity in HF from a Biobank and then draw probability distributions for each physical activity level separately (e.g., three probability distributions for performing physical activity at low, moderate, vagarious intensity).

\section{Recommendations for future research and clinical practice}

Older adults (> 70 years old) living with HF are at risk of low physical activity levels. It is important to explore beliefs about physical activity that are associated with older age. Research informing the development of interventions for this subgroup of the population is needed. The quantitative evidence alone suggests that physical activity probability is reduced in the presence of depression. A better understanding of the mechanism through which depression impacts physical activity in HF and how it can be mitigated is needed. The quantitative evidence on physical activity probability conditioned on other clinical, demographic, and 
medRxiv preprint doi: https://doi.org/10.1101/2021.09.05.21262643; this version posted September 8,2021 . The copyright holder for this preprint (which was not certified by peer review) is the author/funder, who has granted medRxiv a license to display the preprint in It is made available under a CC-BY-NC 4.0 International license.

psychosocial barriers and enablers is uncertain. Research investigating a broad range of clinical, demographic, and psychosocial barriers and enablers to physical activity in HF is warranted.

Social support and self-efficacy to engage in physical activity were identified as considerable enablers according to the qualitative evidence. However, this was not supported by quantitative studies. This indicates that the attributes that define how social support and self-efficacy affect physical activity should be further studied. Finally, less is known about other modifiable determinants of physical activity in HF, which should be addressed in future studies. In addition, identified studies did not explore the mechanism underlying physical activity enactment, including how the barriers and enablers interact, which should be further explored in future research.

Finally, tentative suggestions are made for what a future physical activity intervention needs to include (Table 3). Overall, the review findings indicate that to tackle the barriers and amplify the enablers, a behaviour change intervention containing the following strategies is needed: identity associated with changed behaviour, prompt/cues and adding objects to the environment, behavioural practice/rehearsal, and graded tasks. A previous meta-analysis of randomised controlled trials also suggested that these strategies are associated with the efficacy of interventions (18). In addition, the qualitative evidence included in this review suggests that addressing the change in the social role as a result of acquired HF diagnosis and perceived appropriateness of physical activity in this context need to be addressed. Social Influences, Beliefs about Consequences, Problem Solving, and Emotion via strategies such as social support, information about consequences of the behaviour, problem solving, and reducing negative emotions, may be proven effective in increasing physical activity in HF, according to the present review. However, the latter suggestions need to be considered with caution, considering high uncertainty in the evidence.

\section{Conclusion}

The identified contextual barriers and enablers to physical activity in HF need to be carefully considered when designing interventions and randomised-controlled trials evaluating interventions. However, evidence concerning modifiable barriers and enablers that can be addressed in an intervention to improve physical activity in $\mathrm{HF}$ is uncertain.

The Bayesian approach in this review enabled comparative predictions about barriers and enablers, helped elicit the extent of uncertainty in the evidence and enabled the combination of qualitative and quantitative evidence in a single synthesis. Thus, the present review supports the usefulness of the Bayesian approach to evidence synthesis concerning barriers and enablers to behaviour and in the development of behaviour change interventions.

\section{Protocol:}

The review's protocol was registered on PROSPERO: CRD42021232048

\section{Funding:}

This research was supported by a PhD studentship awarded by City University London. 
medRxiv preprint doi: https://doi.org/10.1101/2021.09.05.21262643; this version posted September 8, 2021. The copyright holder for this preprint (which was not certified by peer review) is the author/funder, who has granted medRxiv a license to display the preprint in It is made available under a CC-BY-NC 4.0 International license.

Availability of data, code, and other materials:

https://github.com/AliyaAM/bayes_meta 
1. Depaoli S, Rus HM, Clifton JP, van de Schoot R, Tiemensma J. An introduction to Bayesian statistics in health psychology. Health Psychol Rev. 2017 Jul 11;11(3):248-64.

2. National Institute for Healthcare and Excellence. NICE: Overview. Chronic heart failure in adults: diagnosis and management. Guidance [Internet]. Overview. Chronic heart failure in adults: diagnosis and management. Guidance. 2018 [cited 2020 Mar 23]. Available from: https://www.nice.org.uk/guidance/ng106

3. Vos T, Allen C, Arora M. Global, regional, and national incidence, prevalence, and years lived with disability for 310 diseases and injuries, 1990-2015: a systematic analysis for the Global Burden of Disease Study 2015. Lancet. 2016 Oct 8;388(10053):1545-602.

4. Lewinter C, Doherty P, Gale CP, Crouch S, Stirk L, Lewin RJ, et al. Exercise-based cardiac rehabilitation in patients with heart failure: a meta-analysis of randomised controlled trials between 1999 and 2013. Eur J Prev Cardiol. 2015 Dec;22(12):1504-12.

5. Davies EJ, Moxham T, Rees K, Singh S, Coats AJS, Ebrahim S, et al. Exercise training for systolic heart failure: Cochrane systematic review and meta-analysis. Eur J Heart Fail. 2010 Jul;12(7):706-15.

6. Sagar VA, Davies EJ, Briscoe S, Coats AJS, Dalal HM, Lough F, et al. Exercise-based rehabilitation for heart failure: systematic review and meta-analysis. Open Heart. 2015 Jan 28;2(1):e000163.

7. Taylor RS, Long L, Mordi IR, Madsen MT, Davies EJ, Dalal H, et al. Exercise-Based Rehabilitation for Heart Failure: Cochrane Systematic Review, Meta-Analysis, and Trial Sequential Analysis. JACC Heart Fail. 2019 Jul 10;7(8):691-705.

8. Belardinelli R, Georgiou D, Cianci G, Purcaro A. 10-year exercise training in chronic heart failure: a randomized controlled trial. J Am Coll Cardiol. 2012 Oct 16;60(16):1521-8.

9. ExTraMATCH Collaborative. Exercise training meta-analysis of trials in patients with chronic heart failure (ExTraMATCH). Bmj. 2004;328(7433).

10. Ponikowski P, Voors AA, Anker SD, Bueno H, Cleland JGF, Coats AJS, et al. 2016 ESC Guidelines for the diagnosis and treatment of acute and chronic heart failure: The Task Force for the diagnosis and treatment of acute and chronic heart failure of the European Society of Cardiology (ESC)Developed with the special contribution of the Heart Failure Association (HFA) of the ESC. Eur Heart J. 2016 Jul 14;37(27):2129-200.

11. Shoemaker MJ, Curtis AB, Vangsnes E, Dickinson MG. Clinically meaningful change estimates for the six-minute walk test and daily activity in individuals with chronic heart failure. Cardiopulm Phys Ther J. 2013 Sep;24(3):21-9.

12. Dibben GO, Dalal HM, Taylor RS, Doherty P, Tang LH, Hillsdon M. Cardiac rehabilitation and physical activity: systematic review and meta-analysis. Heart. $2018 \mathrm{Apr}$ 13;104(17):1394-402.

13. WHO. Physical activity [Internet]. [cited 2020 Mar 1]. Available from: https://www.who.int/news-room/fact-sheets/detail/physical-activity

14. Doherty PJ, Harrison AS. The National Audit of Cardiac Rehabilitation: Annual Statistical Report 2017. 2017;

15. Jaarsma T, Strömberg A, Ben Gal T, Cameron J, Driscoll A, Duengen H-D, et al. Comparison of self-care behaviors of heart failure patients in 15 countries worldwide. Patient Educ Couns. 2013 Jul;92(1):114-20.

16. O’Donnell J, Smith-Byrne K, Velardo C, Conrad N, Salimi-Khorshidi G, Doherty A, et al. Self-reported and objectively measured physical activity in people with and without chronic heart failure: UK Biobank analysis. Open Heart. 2020 Feb 19;7(1):e001099.

17. Conraads VM, Deaton C, Piotrowicz E, Santaularia N, Tierney S, Piepoli MF, et al. Adherence of HF patients to exercise: barriers and possible solutions. European journal of 
HF. 2012;14(5):451-8.

18. Amirova A, Fteropoulli T, Williams P, Haddad M. Efficacy of interventions to increase physical activity for people with heart failure: a meta-analysis. Open Heart. 2021 May 4;

19. Tierney S, Mamas M, Skelton D, Woods S, Rutter MK, Gibson M, et al. What can we learn from patients with heart failure about exercise adherence? A systematic review of qualitative papers. Health Psychol. 2011 Jul;30(4):401-10.

20. Brodie DA, Inoue A. Motivational interviewing to promote physical activity for people with chronic heart failure. J Adv Nurs. 2005 Jun;50(5):518-27.

21. Dalal HM, Taylor RS, Jolly K, Davis RC, Doherty P, Miles J, et al. The effects and costs of home-based rehabilitation for heart failure with reduced ejection fraction: The REACH-HF multicentre randomized controlled trial. Eur J Prev Cardiol. 2019 Feb;26(3):262-72.

22. Freedland KE, Carney RM, Rich MW, Steinmeyer BC, Rubin EH. Cognitive Behavior Therapy for Depression and Self-Care in Heart Failure Patients: A Randomized Clinical Trial. JAMA Intern Med. 2015 Nov;175(11):1773-82.

23. Pozehl BJ, McGuire R, Duncan K, Kupzyk K, Norman J, Artinian NT, et al. Effects of the HEART camp trial on adherence to exercise in patients with heart failure. J Card Fail. 2018 Oct;24(10):654-60.

24. Smeulders ES, van Haastregt JC, Ambergen T, Uszko-Lencer NH, Janssen-Boyne JJ, Gorgels AP, et al. Nurse-led self-management group programme for patients with congestive HF: randomized controlled trial. Journal of advanced nursing. 2010;66(7):1487-99.

25. O'Connor CM, Whellan DJ, Lee KL, Keteyian SJ, Cooper LS, Ellis SJ, et al. Efficacy and safety of exercise training in patients with chronic HF: HF-ACTION randomized controlled trial. Jama. 2009;301(14):1439-50.

26. Craig P, Dieppe P, Macintyre S, Michie S, Nazareth I, Petticrew M, et al. Developing and evaluating complex interventions: The new Medical Research Council guidance. BMJ. 2008 Sep 29;337:a1655.

27. Hagger MS, Cameron LD, Hamilton K, Hankonen N, Lintunen T, editors. The handbook of behavior change. Cambridge University Press; 2020.

28. Michie S, Atkins L, West R. The behaviour change wheel. A guide to designing interventions 1st ed Great Britain: Silverback Publishing. 2014;1003-10.

29. O'Cathain A, Croot L, Sworn K, Duncan E, Rousseau N, Turner K, et al. Taxonomy of approaches to developing interventions to improve health: a systematic methods overview. Pilot Feasibility Stud. 2019 Mar 12;5:41.

30. Kok G, Gottlieb NH, Peters G-JY, Mullen PD, Parcel GS, Ruiter RAC, et al. A taxonomy of behaviour change methods: an Intervention Mapping approach. Health Psychol Rev. 2016 Sep;10(3):297-312.

31. Araújo-Soares V, Hankonen N, Presseau J, Rodrigues A, Sniehotta FF. Developing Behavior Change Interventions for Self-Management in Chronic Illness: An Integrative Overview. Eur Psychol. 2019;24(1):7-25.

32. Beard E, West R. Using Bayesian statistics in health psychology: a comment on Depaoli et al. (2017). Health Psychol Rev. 2017;11(3):298-301.

33. Heino MTJ, Vuorre M, Hankonen N. Bayesian evaluation of behavior change interventions: a brief introduction and a practical example. Health Psychol Behav Med. 2018 Jan;6(1):4978.

34. Hamilton K, Marques MM, Johnson BT. Advanced analytic and statistical methods in health psychology. Health Psychol Rev. 2017 Jul 3;11(3):217-21.

35. Roberts KA, Dixon-Woods M, Fitzpatrick R, Abrams KR, Jones DR. Factors affecting uptake of childhood immunisation: a Bayesian synthesis of qualitative and quantitative evidence. Lancet. 2002 Nov 16;360(9345):1596-9.

36. Spiegelhalter DJ, Abrams KR, Myles JP. Bayesian Approaches to Clinical Trials and 
Health-Care Evaluation. Chichester, UK: John Wiley \& Sons, Ltd; 2003.

37. Cane J, O'Connor D, Michie S. Validation of the theoretical domains framework for use in behaviour change and implementation research. Implement Sci. 2012 Apr 24;7:37.

38. Michie S, van Stralen MM, West R. The behaviour change wheel: a new method for characterising and designing behaviour change interventions. Implement Sci. 2011 Apr $23 ; 6: 42$.

39. Connell LE, Carey RN, de Bruin M, Rothman AJ, Johnston M, Kelly MP, et al. Links between behavior change techniques and mechanisms of action: an expert consensus study. Ann Behav Med. 2019 Jul 17;53(8):708-20.

40. Michie S, Wood CE, Johnston M, Abraham C, Francis JJ, Hardeman W. Behaviour change techniques: the development and evaluation of a taxonomic method for reporting and describing behaviour change interventions (a suite of five studies involving consensus methods, randomised controlled trials and analysis of qualitative data). Health Technol Assess. 2015 Nov;19(99):1-188.

41. Dekkers OM, Vandenbroucke JP, Cevallos M, Renehan AG, Altman DG, Egger M. COSMOS-E: Guidance on conducting systematic reviews and meta-analyses of observational studies of etiology. PLoS Med. 2019 Feb 21;16(2):e1002742.

42. von Elm E, Altman DG, Egger M, Pocock SJ, Gøtzsche PC, Vandenbroucke JP, et al. Strengthening the Reporting of Observational Studies in Epidemiology (STROBE) statement: guidelines for reporting observational studies. BMJ. 2007 Oct 20;335(7624):8068.

43. Page MJ, McKenzie JE, Higgins JPT. Tools for assessing risk of reporting biases in studies and syntheses of studies: a systematic review. BMJ Open. 2018 Mar 14;8(3):e019703.

44. Sanderson S, Tatt ID, Higgins JPT. Tools for assessing quality and susceptibility to bias in observational studies in epidemiology: a systematic review and annotated bibliography. Int J Epidemiol. 2007 Jun;36(3):666-76.

45. Viswanathan M, Berkman ND, Dryden DM, Hartling L. Assessing risk of bias and confounding in observational studies of interventions or exposures: further development of the RTI item bank. Rockville (MD): Agency for Healthcare Research and Quality (US); 2013.

46. van Aert RCM, Jackson D. A new justification of the Hartung-Knapp method for randomeffects meta-analysis based on weighted least squares regression. Res Synth Methods. 2019 Dec;10(4):515-27.

47. Atkins L, Francis J, Islam R, O'Connor D, Patey A, Ivers N, et al. A guide to using the Theoretical Domains Framework of behaviour change to investigate implementation problems. Implement Sci. 2017 Jun 21;12(1):77.

48. Goldstein CM, Gathright EC, Garcia S. Relationship between depression and medication adherence in cardiovascular disease: the perfect challenge for the integrated care team. Patient Prefer Adherence. 2017 Mar 15;11:547-59.

49. Moudgil R, Haddad H. Depression in heart failure. Curr Opin Cardiol. 2013 Mar;28(2):24958.

50. Huffman JC, Celano CM, Beach SR, Motiwala SR, Januzzi JL. Depression and cardiac disease: epidemiology, mechanisms, and diagnosis. Cardiovasc Psychiatry Neurol. 2013 Apr 7;2013:695925.

51. Gold SM, Köhler-Forsberg O, Moss-Morris R, Mehnert A, Miranda JJ, Bullinger M, et al. Comorbid depression in medical diseases. Nat Rev Dis Primers. 2020 Aug 20;6(1):69.

52. McDonald S, O'Brien N, White M, Sniehotta FF. Changes in physical activity during the retirement transition: a theory-based, qualitative interview study. Int J Behav Nutr Phys Act. 2015 Feb 21;12:25.

53. Chaudhury M, Shelton N. Physical activity among 60-69-year-olds in England: knowledge, 
perception, behaviour and risk factors. Ageing Soc. 2010 Nov;30(8):1343-55.

54. Koeneman MA, Chorus A, Hopman-Rock M, Chinapaw MJM. A novel method to promote physical activity among older adults in residential care: an exploratory field study on implicit social norms. BMC Geriatr. 2017 Jan 6;17(1):8.

55. McPhee JS, French DP, Jackson D, Nazroo J, Pendleton N, Degens H. Physical activity in older age: perspectives for healthy ageing and frailty. Biogerontology. 2016 Mar 2;17(3):567-80.

56. Rushton CA, Satchithananda DK, Jones PW, Kadam UT. Non-cardiovascular comorbidity, severity and prognosis in non-selected heart failure populations: A systematic review and meta-analysis. Int J Cardiol. 2015 Oct 1;196:98-106.

57. Ling L-H, Kistler PM, Kalman JM, Schilling RJ, Hunter RJ. Comorbidity of atrial fibrillation and heart failure. Nat Rev Cardiol. 2016 Mar;13(3):131-47.

58. Gray E, Dasanayake S, Sangelaji B, Hale L, Skinner M. Factors influencing physical activity engagement following coronary artery bypass graft surgery: A mixed methods systematic review. Heart Lung. 2021 Jun 1;50(5):589-98.

59. Rothman KJ, Lash TL, Greenland S. Modern Epidemiology. 2008.

60. Spiteri K, Broom D, Bekhet AH, de Caro JX, Laventure B, Grafton K. Barriers and Motivators of Physical Activity Participation in Middle-aged and Older-adults - A Systematic Review. J Aging Phys Act. 2019 Sep 1;27(4):929-44.

61. Dixon-Woods M, Agarwal S, Jones D, Young B, Sutton A. Synthesising qualitative and quantitative evidence: a review of possible methods. J Health Serv Res Policy. 2005 Jan $1 ; 10(1): 45-53$.

62. Albert I, Donnet S, Guihenneuc-Jouyaux C, Low-Choy S, Mengersen K, Rousseau J. Combining Expert Opinions in Prior Elicitation. Bayesian Anal. 2012 Sep;7(3):503-32.

63. Lewis MG, Nair NS. Review of applications of Bayesian meta-analysis in systematic reviews. Global Journal of Medicine and Public Health. 2015;4(1):1-9.

64. Newman DA, Jacobs RR, Bartram D. Choosing the best method for local validity estimation: Relative accuracy of meta-analysis versus a local study versus Bayes-analysis. Journal of Applied Psychology. 2007 Sep;92(5):1394-413.

65. Lemoine NP. Moving beyond noninformative priors: why and how to choose weakly informative priors in Bayesian analyses. Oikos. $2019 \mathrm{Jul}$;28(7):912-28.

66. Chen M-H, Ibrahim JG, Kim S. Properties and implementation of jeffreys's prior in binomial regression models. J Am Stat Assoc. 2008 Dec 1;103(484):1659-64.

67. Evangelista L, Doering LV, Dracup K, Westlake C, Hamilton M, Fonarow GC. Compliance behaviors of elderly patients with advanced heart failure. J Cardiovasc Nurs. 2003 Aug;18(3):197-206; quiz 207.

68. Evangelista LS, Berg J, Dracup K. Relationship between psychosocial variables and compliance in patients with heart failure. Heart Lung. 2001 Aug;30(4):294-301.

69. Chien H-C, Chen H-M, Garet M, Wang R-H. Predictors of physical activity in patients with heart failure: a questionnaire study. J Cardiovasc Nurs. 2014 Jul;29(4):324-31.

70. Snipelisky D, Kelly J, Levine JA, Koepp GA, Anstrom KJ, McNulty SE, et al. Accelerometer-Measured Daily Activity in Heart Failure With Preserved Ejection Fraction: Clinical Correlates and Association With Standard Heart Failure Severity Indices. Circ Heart Fail. 2017 Jun;10(6):e003878.

71. Witham MD, Argo IS, Johnston DW, Struthers AD, McMurdo MET. Predictors of exercise capacity and everyday activity in older heart failure patients. Eur J Heart Fail. 2006 Mar;8(2):203-7.

72. Lee H, Boo S, Yu J, Suh S-R, Chun KJ, Kim JH. Physical Functioning, Physical Activity, Exercise Self-Efficacy, and Quality of Life Among Individuals With Chronic Heart Failure in Korea: A Cross-Sectional Descriptive Study. J Nurs Res. 2016 Jun 27; 
73. Pozehl BJ, Mcguire R, Duncan K, Hertzog M, Deka P, Norman J, et al. AccelerometerMeasured Daily Activity Levels and Related Factors in Patients With Heart Failure. J Cardiovasc Nurs. 2018;33(4):329-35.

74. Alosco ML, Spitznagel MB, Miller L, Raz N, Cohen R, Sweet LH, et al. Depression is associated with reduced physical activity in persons with heart failure. Health Psychol. 2012 Nov;31(6):754-62.

75. Dontje ML, van der Wal MHL, Stolk RP, Brügemann J, Jaarsma T, Wijtvliet PEPJ, et al. Daily physical activity in stable heart failure patients. J Cardiovasc Nurs. 2014 Jun;29(3):218-26.

76. Klompstra L, Jaarsma T, Strömberg A. Self-efficacy Mediates the Relationship Between Motivation and Physical Activity in Patients With Heart Failure. J Cardiovasc Nurs. 2018;33(3):211-6.

77. Corvera-Tindel T, Doering LV, Gomez T, Dracup K. Predictors of noncompliance to exercise training in heart failure. J Cardiovasc Nurs. 2004 Aug;19(4):269-77; quiz 278.

78. Gallagher R, Luttik M-L, Jaarsma T. Social support and self-care in heart failure. J Cardiovasc Nurs. 2011 Dec;26(6):439-45.

79. Werhahn SM, Dathe H, Rottmann T, Franke T, Vahdat D, Hasenfuß G, et al. Designing meaningful outcome parameters using mobile technology: a new mobile application for telemonitoring of patients with heart failure. ESC Heart Fail. 2019 Mar 13;6(3):516-25.

80. Oka RK, Gortner SR, Stotts NA, Haskell WL. Predictors of physical activity in patients with chronic heart failure secondary to either ischemic or idiopathic dilated cardiomyopathy. Am J Cardiol. 1996 Jan 15;77(2):159-63.

81. van der Wal MHL, van Veldhuisen DJ, Veeger NJGM, Rutten FH, Jaarsma T. Compliance with non-pharmacological recommendations and outcome in heart failure patients. Eur Heart J. 2010 Jun;31(12):1486-93.

82. Moreno-Suarez I, Liew S, Dembo LG, Larbalestier R, Maiorana A. Physical Activity Is Higher in Patients with LVADs Compared to Chronic Heart Failure. Med Sci Sports Exerc. 2019 Jul 24;

83. Jaarsma T, Arestedt KF, Mårtensson J, Dracup K, Strömberg A. The European Heart Failure Self-care Behaviour scale revised into a nine-item scale (EHFScB-9): a reliable and valid international instrument. Eur J Heart Fail. 2009 Jan;11(1):99-105.

84. Nelson TD, Benson ER, Jensen CD. Negative attitudes toward physical activity: measurement and role in predicting physical activity levels among preadolescents. J Pediatr Psychol. 2010 Feb;35(1):89-98.

85. Ware JE, Sherbourne CD. The MOS 36-item short-form health survey (SF-36). I. Conceptual framework and item selection. Med Care. 1992 Jun;30(6):473-83.

86. Faller H, Steinbüchel T, Schowalter M, Spertus JA, Störk S, Angermann CE. [The Kansas City Cardiomyopathy Questionnaire (KCCQ) -- a new disease-specific quality of life measure for patients with chronic heart failure]. Psychother Psychosom Med Psychol. 2005 Apr;55(3-4):200-8.

87. Resnick B, Jenkins LS. Testing the reliability and validity of the Self-Efficacy for Exercise scale. Nur.s Res. 2000 Jun;49(3):154-9.

88. Ainsworth BE. How do I measure physical activity in my patients? Questionnaires and objective methods. Br J Sports Med. 2009 Jan;43(1):6-9.

89. Liou YL, Tsai JC, Jeng C. Physical symptom distress, physical bypass grafting surgery. . J Evid Based Nurs. 2007;3(1).

90. Hlatky MA, Boineau RE, Higginbotham MB, Lee KL, Mark DB, Califf RM, et al. A brief self-administered questionnaire to determine functional capacity (the Duke Activity Status Index). Am J Cardiol. 1989 Sep 15;64(10):651-4.

91. Chang VT, Hwang SS, Feuerman M, Kasimis BS, Thaler HT. The memorial symptom 
assessment scale short form (MSAS-SF). Cancer. 2000 Sep 1;89(5):1162-71.

92. American Psychological Association. APA Dictionary of Psychology. American Psychological Association, editor. Washington, DC: American Psychological Association; 2007.

93. National Institute for Health, Excellence C. Chronic HF: the management of adults with chronic HF in primary and secondary care (partial update). (Clinical guideline 108). Annals of internal medicine; 2011.

94. Azzolina D, Berchialla P, Gregori D, Baldi I. Prior elicitation for use in clinical trial design and analysis: A literature review. Int J Environ Res Public Health. 2021 Feb 13;18(4).

95. O'Hagan A. Eliciting expert beliefs in substantial practical applications [Read before The Royal Statistical Society at ameeting on "Elicitation" on Wednesday, april 16th, 1997, the President, Professor A. F. M. Smithin the Chair]. J Royal Statistical Soc D. 1998 Mar;47(1):21-35.

96. Viechtbauer W. Conducting Meta-Analyses in R with the metafor Package. J Stat Softw. 2010;36(3). 


\begin{tabular}{|c|c|c|c|c|c|c|}
\hline Author, year & Country & Study design & Study aims/objective & Additional inclusion criteria & Sample & The summary of the main findings \\
\hline $\begin{array}{l}\text { Alosco et al., } \\
2012\end{array}$ & USA & $\begin{array}{l}\text { A cross-sectional } \\
\text { study }\end{array}$ & $\begin{array}{l}\text { To examine the } \\
\text { role of } \\
\text { depression in } \\
\text { physical activity } \\
\text { in HF as } \\
\text { assessed using } \\
\text { accelerometers. } \\
\text { To determine if } \\
\text { low physical } \\
\text { activity is } \\
\text { associated with } \\
\text { death and } \\
\text { hospitalisation. }\end{array}$ & $\begin{array}{l}\text { Age: } 50-85 \text { years old; NYHA } \\
\text { class: II and III; without any } \\
\text { history of severe neurological } \\
\text { disease, injury, sleep apnoea, } \\
\text { renal failure and substance abuse }\end{array}$ & $\begin{array}{l}\quad \mathrm{N}=96 \\
\text { Mean age = } \\
69.81(\mathrm{SD}= \\
8.79) ; \\
\text { Male: } \mathrm{N}= \\
60(63.5 \%)\end{array}$ & $\begin{array}{l}\text { The number of years of education was } \\
\text { significantly associated with a number of } \\
\text { steps }(\mathrm{b}=0.21, \mathrm{p}<0.05) \text { in a simple linear } \\
\text { regression. Age, gender, and comorbidities } \\
\text { were not identified as significant individual } \\
\text { predictors of step count. When adjusted for } \\
\text { comorbidity, age was identified as a } \\
\text { significant predictor of the daily step count. } \\
\text { Comorbidities were not suggested to be } \\
\text { associated with the outcome when adjusting } \\
\text { for age, gender and education. When } \\
\text { adjusting for age, gender, comorbidities and } \\
\text { education, the increased depression (BDI-II) } \\
\text { was associated with the decreased daily } \\
\text { count. }\end{array}$ \\
\hline Chien et al., 2014 & Taiwan & $\begin{array}{c}\text { A prospective } \\
\text { observational study }\end{array}$ & $\begin{array}{l}\text { To explore } \\
\text { physical activity } \\
\text { predictors (as } \\
\text { assessed at } \\
\text { discharge) one } \\
\text { month after } \\
\text { discharge. }\end{array}$ & $\begin{array}{l}75 \text { years old or younger; NYHA } \\
\text { class: I-III. }\end{array}$ & $\begin{array}{l}\quad \mathrm{N}=111 \\
\text { Mean age = } \\
63.2(\mathrm{SD}= \\
11.5) ; \\
\text { Male: } \mathrm{N}= \\
69(62.2 \%)\end{array}$ & $\begin{array}{l}\text { 19.12\% of daily energy expenditure (DEE) } \\
\text { was within low intensity (<three METs), } \\
7.20 \% \text { within high (3-5 METs), and only } \\
1.42 \% \text { was intensive (>five METs). BMI, } \\
\text { age, self-efficacy for instrumental activities } \\
\text { of daily living, and educational level were } \\
\text { predictors of total DEE one month after } \\
\text { discharge. Self-efficacy for instrumental } \\
\text { activities of daily living, gender, and BMI } \\
\text { were predictors of high DEE. Age, BMI, } \\
\text { and symptom distress were predictors of } \\
\text { intensive DEE. }\end{array}$ \\
\hline $\begin{array}{l}\text { Corvera-Tindel et } \\
\text { al., } 2004\end{array}$ & USA & $\begin{array}{c}\text { A prospective } \\
\text { observational study }\end{array}$ & $\begin{array}{l}\text { To evaluate } \\
\text { clinical and } \\
\text { psychosocial } \\
\text { characteristics }\end{array}$ & - & $\begin{array}{l}\mathrm{N}=39 \\
\text { Mean age no } \\
\text { reported, }\end{array}$ & $\begin{array}{l}\text { Compliance with the recommendation to } \\
\text { walk weekly was associated with higher HF } \\
\text { ot duration, higher comorbidity, lower BMI, } \\
\text { and lower hostility }\end{array}$ \\
\hline
\end{tabular}




\begin{tabular}{|c|c|c|c|c|c|c|}
\hline Author, year & Country & Study design & Study aims/objective & Additional inclusion criteria & Sample & The summary of the main findings \\
\hline $\begin{array}{l}\text { Dontje et al., } \\
2014\end{array}$ & Netherlands & $\begin{array}{l}\text { A cross-sectional } \\
\text { study }\end{array}$ & $\begin{array}{l}\text { among exercise } \\
\text { complaint and } \\
\text { non-compliant } \\
\text { HF patients. }\end{array}$ & $\begin{array}{l}\text { NYHA class: I and III; with 1- } \\
\text { year survival prognosis; without } \\
\text { any implantable devices; who } \\
\text { have not undergone any surgical } \\
\text { interventions; without AF and } \\
\text { arrhythmia; without a recent } \\
\text { embolism. }\end{array}$ & $\begin{array}{l}\mathrm{N}=68 \\
\text { Mean age }= \\
62(\mathrm{SD}= \\
14), \text { Male: } \\
\mathrm{N}=48 \\
(71 \%)\end{array}$ & $\begin{array}{c}\text { Sig. difference in steps/day between } \\
\text { patients within NYHA I-II } \\
\text { (median=6113) and patients within } \\
\text { NYHA III (median=3150) }(\mathrm{p}<0.001) \text {; } \\
\text { between patients with } \mathrm{EF} \leq 40 \text { (median= } \\
5854 \text { ) and patients with EF } \\
>40(\text { median }=3246)(\mathrm{p}<0.05) \text {; no } \\
\text { significant difference in steps/day } \\
\text { between men and women }(\mathrm{p}=0.389) \text {. } \\
\text { Steps/day was only significantly } \\
\text { correlated to age (Spearman's rho=-.43) } \\
\text { and self-efficacy (Spearman's rho=.40), } \\
\text { but not to other characteristics. NYHA } \\
\text { classification, EF, age, and self-efficacy } \\
\text { explained } 42 \% \text { of the variance in } \\
\text { steps/day ( } \mathrm{F}=8.69 ; \mathrm{p}<0.001) \text { in a linear } \\
\text { regression model. }\end{array}$ \\
\hline $\begin{array}{l}\text { Evangelista et al., } \\
2001\end{array}$ & USA & $\begin{array}{l}\text { A cross-sectional } \\
\text { study }\end{array}$ & $\begin{array}{l}\text { To identify } \\
\text { precipitating } \\
\text { determinants of } \\
\text { self-care } \\
\text { noncompliance. }\end{array}$ & - & $\begin{array}{l}\quad \mathrm{N}=82 \\
\\
<60 \text { y.old: } \\
\mathrm{N}=52 \\
(63.4 \%) \\
\text { Male: } \mathrm{N}= \\
51(62.2 \%)\end{array}$ & $\begin{array}{l}\text { Significant correlates of exercise } \\
\text { compliance included higher physical }(\mathrm{r} \\
=0.507) \text { and mental health }(\mathrm{r}=0.468) \\
\text { and health satisfaction }(\mathrm{r}=0.435) \\
\text { lower neuroticism scores }(\mathrm{r}=- \\
\text { 0.317).Age, race, education, and marital } \\
\text { status were not significantly associated } \\
\text { with physical activity levels. }\end{array}$ \\
\hline $\begin{array}{l}\text { Evangelista et al., } \\
2003\end{array}$ & USA & $\begin{array}{l}\text { A case-controlled } \\
\text { (matched) cross- } \\
\text { sectional study }\end{array}$ & $\begin{array}{l}\text { To describe } \\
\text { physical activity } \\
\text { differences in } \\
\text { older ( }>70 \text { years } \\
\text { old) and }\end{array}$ & $\begin{array}{l}\text { Diagnosis duration for over a } \\
\text { year }\end{array}$ & $\begin{array}{l}\mathrm{N}=140 \\
\text { Mean age = } \\
68.59\end{array}$ & $\begin{array}{l}\text { The mean compliance score was } \\
\text { significantly different between older }(>70 \\
\text { y. old) and younger }(<70 \text { y. old }) \text { adults, } \\
67.14 \pm 32.28 \text { and } 55.00 \pm 29.05 \\
\text { respectively, } \mathrm{p}=0.021\end{array}$ \\
\hline
\end{tabular}




\begin{tabular}{|c|c|c|c|c|c|c|}
\hline Author, year & Country & Study design & Study aims/objective & ditional inclusion criteria & Sample & The summary of the main findings \\
\hline $\begin{array}{l}\text { Gallagher et al., } \\
2011\end{array}$ & USA & $\begin{array}{l}\text { RCT; only the } \\
\text { results of the } \\
\text { baseline } \\
\text { assessment were } \\
\text { included in this } \\
\text { review }\end{array}$ & $\begin{array}{c}\text { younger }(<70) \\
\text { individuals } \\
\text { diagnosed with } \\
\text { HF } \\
\text { To determine } \\
\text { the types and } \\
\text { level of social } \\
\text { support in HF } \\
\text { provided by } \\
\text { partners; to } \\
\text { evaluate the } \\
\text { impact of the } \\
\text { partner's social } \\
\text { support levels } \\
\text { on self-care } \\
\text { behaviours } \\
\text { compared to an } \\
\text { individual } \\
\text { without partners } \\
\text { on HF. }\end{array}$ & $\begin{array}{l}\text { Not scheduled for or underwent } \\
\text { any surgical interventions in the } \\
\text { past six months }\end{array}$ & $\begin{array}{l}\quad \mathrm{N}=333 \\
\text { Mean age = } \\
72 \\
(\mathrm{SD}=11), \\
\text { Male: } \mathrm{N}= \\
220(66 \%)\end{array}$ & $\begin{array}{l}\text { The extent of regular exercise ('I exercise } \\
\text { regularly': 5-point Likert scale) between } \\
\text { groups with low social support (no } \\
\text { partner), medium, and high was } \\
\text { significantly different, mean }=2.95 \\
(\mathrm{SD}=1.28), \text { mean }=2.81 \text { ( } \mathrm{SD}=1.27) \text {, mean } \\
=2.41(\mathrm{SD}=1.29) \text {, respectively. The } \\
\text { authors concluded that not having a } \\
\text { partner did not significantly change } \\
\text { physical activity levels in individuals with } \\
\text { HF. However, the perception of low social } \\
\text { support vs high social support did. }\end{array}$ \\
\hline $\begin{array}{l}\text { Klompstra et al., } \\
2018\end{array}$ & Sweden & $\begin{array}{l}\text { A cross-sectional } \\
\text { study }\end{array}$ & $\begin{array}{l}\text { To evaluate the } \\
\text { mediating role of } \\
\text { exercise self-efficacy on } \\
\text { the relationship between } \\
\text { motivation and physical } \\
\text { activity. }\end{array}$ & $\begin{array}{l}\text { With life expectancy not shorter } \\
\text { than six months }\end{array}$ & $\begin{array}{l}\mathrm{N}=100 \\
\text { Mean age = } 70 \\
(\mathrm{SD}=10), \\
\text { Male: } \mathrm{N}=73 \\
(73 \%)\end{array}$ & $\begin{array}{l}\text { Exercise motivation significantly } \\
\text { predicted physical activity in a } \\
\text { bivariate linear regression }(\mathrm{b}=0.58, p \\
=.02) \text {. After controlling for exercise } \\
\text { self-efficacy, the effect of exercise } \\
\text { motivation on physical activity was } \\
\text { zero }(\mathrm{b}=0.76, \mathrm{P}=.06) \text {. Authors } \\
\text { concluded that self-efficacy fully } \\
\text { mediated the effect of motivation on } \\
\text { physical activity. Age }(\mathrm{b}=-0.03, \mathrm{P}= \\
.22) \text {, and NYHA class }(\mathrm{b}=-0.41, \mathrm{P}= \\
\text {.46) did not predict the amount of } \\
\text { physical activity }\end{array}$ \\
\hline
\end{tabular}




\begin{tabular}{|c|c|c|c|c|c|c|}
\hline Author, year & Country & Study design & Study aims/objective & Additional inclusion criteria & Sample & The summary of the main findings \\
\hline Lee et al., 2016 & South Korea & $\begin{array}{l}\text { A cross-sectional } \\
\text { study }\end{array}$ & $\begin{array}{l}\text { To describe the } \\
\text { relationships between } \\
\text { physical functioning, } \\
\text { physical activity, } \\
\text { exercise self-efficacy, } \\
\text { and QOL in individuals } \\
\text { with CHF. }\end{array}$ & - & $\begin{array}{l}\mathrm{N}=116 \\
62.15(9.06) \\
93(80.2)\end{array}$ & $\begin{array}{l}\text { Correlations between physical activity } \\
\text { and self-efficacy, quality of life, age, } \\
\text { income, education, and LVEF were } \\
\text { assessed. Physical activity significantly } \\
\text { and negatively correlated with age }(\mathrm{r}=- \\
0.194, \mathrm{p}<0.01)\end{array}$ \\
\hline $\begin{array}{l}\text { Moreno-Soarez et } \\
\text { al., } 2019\end{array}$ & Australia & $\begin{array}{l}\text { A case-controlled } \\
\text { prospective } \\
\text { study(well- } \\
\text { matched patients } \\
\text { with a Left } \\
\text { Ventricular Assist } \\
\text { Device (LVAD) } \\
\text { versus well- } \\
\text { matched patients } \\
\text { with CHF, but no } \\
\text { LVAD) }\end{array}$ & $\begin{array}{l}\text { To describe daily PA } \\
\text { levels in patients with } \\
\text { LVAD support } \\
\text { compared with well- } \\
\text { matched participants } \\
\text { with advanced CHF } \\
\text { without LVAD support. }\end{array}$ & Without hypertension & $\begin{array}{l}\mathrm{N}=32 \\
\text { Exposed: } \\
\text { Mean age: } \\
\text { 59.1 (SD = } \\
\text { 10.8), Male: N } \\
=26(81 \%) \\
\text { Unexposed: } \\
\text { Mean age: } \\
\text { 58.3 (SD=8.7), } \\
\text { Male: } \mathrm{N}=26 \\
(81 \%)\end{array}$ & $\begin{array}{l}\text { In a matched for age }( \pm 5 \mathrm{yr} .) \text {, sex, and } \\
\text { New York Heart Association (NYHA) } \\
\text { class, cohort study, participants with a } \\
\text { fitted LVAD had higher levels of energy } \\
\text { expenditure than individuals with HF } \\
\text { who were not fitted with the device, } \\
404.1 \pm 169.1 \mathrm{kcal} / \mathrm{d} \text { ay and } 222.5 \pm \\
163.4 \mathrm{kcal} / \mathrm{day} \text {, respectively. }\end{array}$ \\
\hline Oka et al., 1996 & USA & $\begin{array}{l}\text { A cross-sectional } \\
\text { study }\end{array}$ & $\begin{array}{l}\text { To describe the } \\
\text { relationship between } \\
\text { Knowledge, attitudes } \\
\text { and beliefs, and } \\
\text { physical activity levels } \\
\text { in HF patients. }\end{array}$ & $\begin{array}{c}\text { Diagnosis duration for at } \\
\text { least } 23 \text { months; without } \\
\text { obstructive valvular } \\
\text { disease; congenital hear1 } \\
\text { disease; and tachycardia } \\
\text { pacemakers; severe } \\
\text { pulmonary hypertension }\end{array}$ & $\begin{array}{l}\mathrm{N}=43 \\
\text { Median age: } \\
\text { 59.9 [IQR: } \\
\text { 33;91], Male: } \mathrm{N} \\
=35(81.4 \%)\end{array}$ & $\begin{array}{l}\text { The association between physical } \\
\text { activity and physical fitness (peak } \\
\text { VO2); Knowledge, attitudes, and } \\
\text { beliefs including self-efficacy for } \\
\text { general activity, perceived exertion } \\
\text { during daily activity; and marital } \\
\text { status) was assessed. Self-efficacy ( } \mathrm{p}= \\
\text { 0.015) was the strongest predictor of } \\
\text { physical activity. }\end{array}$ \\
\hline
\end{tabular}




\begin{tabular}{|c|c|c|c|c|c|c|}
\hline Author, year & Country & Study design & Study aims/objective & tional inclusion criteria & Sample & The summary of the main findings \\
\hline Pihl et al., 2011 & Sweden & $\begin{array}{l}\text { Phenomenological } \\
\text { analysis of } \\
\text { qualitative } \\
\text { interviews }\end{array}$ & $\begin{array}{c}\text { To describe } \\
\text { qualitatively how } \\
\text { individuals with HF } \\
\text { conceived their } \\
\text { limitations in daily life } \\
\text { activities. }\end{array}$ & $\begin{array}{l}\text { A stratified recruitment } \\
\text { strategy to obtain variation } \\
\text { in the sample in terms of } \\
\text { gender, age, place of } \\
\text { residence, education, and } \\
\text { NYHA class. }\end{array}$ & $\begin{array}{l}\mathrm{N}=15 \\
\text { Mean age not } \\
\text { reported, } \\
\text { Male: not } \\
\text { reported }\end{array}$ & $\begin{array}{l}\text { The study supported the relevance of } \\
\text { the following domains to physical } \\
\text { activity in HF: Knowledge, } \\
\text { Social/Professional Role and Identity, } \\
\text { Beliefs about Capabilities, Beliefs } \\
\text { about Consequences, Goals (low } \\
\text { relevance), Memory, attention and } \\
\text { decision processes (low relevance), } \\
\text { Social Influences, Emotion, and } \\
\text { Behavioural Regulation. }\end{array}$ \\
\hline Pozehl et al., 2018 & USA & $\begin{array}{l}\mathrm{RCT} \text {; only the } \\
\text { results of the } \\
\text { baseline } \\
\text { assessment were } \\
\text { included in this } \\
\text { review }\end{array}$ & $\begin{array}{l}\text { To describe physical } \\
\text { activity levels (using } \\
\text { accelerometry), } \\
\text { operationalised as } \\
\text { MVPA or EE; to } \\
\text { determine the } \\
\text { proportion meeting the } \\
\text { recommended levels of } \\
\text { physical activity; to } \\
\text { describe determinants } \\
\text { associated with physical } \\
\text { activity. }\end{array}$ & $\begin{array}{c}\text { Coronary artery bypass surgery, } \\
\text { or biventricular pacemaker less } \\
\text { than six weeks prior; } \\
\text { participation in } 3 \text { times per week } \\
\text { aerobic exercise in the past eigh } \\
\text { weeks; plans to move more than } \\
50 \text { miles from the exercise site } \\
\text { within the next year; peak oxyge } \\
\text { uptake (pVO2) in females }>21 \\
\text { ml/kg/min and in males }>24 \\
\mathrm{ml} / \mathrm{kg} / \mathrm{min} \text {; and pregnancy } \\
\text { planned or current. }\end{array}$ & $\begin{array}{l}\mathrm{N}=204 \\
\text { Mean age }= \\
60.4(\mathrm{SD}=11.5) \\
\text { Male: } \mathrm{N}=224 \\
(56 \%)\end{array}$ & $\begin{array}{l}\text { The MVPA (mins/day) was } \\
\text { significantly higher in males ( than } \\
\text { females } \mathrm{p}<0.01) \text {, Caucasians than } \\
\text { non-Caucasian }(\mathrm{p}<0.05 \text { ), those within } \\
\text { NYHA class II compared to those } \\
\text { within NYHA class III. The higher } \\
\text { Charlson comorbidity index and } \\
\text { PROMIS anxiety score were } \\
\text { significantly associated with a higher } \\
\text { level of MVPA. The ejection fraction } \\
\text { was not significantly correlated with } \\
\text { MVPA. }\end{array}$ \\
\hline $\begin{array}{c}\text { Snipelisky et al., } \\
2017\end{array}$ & USA & $\begin{array}{l}\text { RCT; only the } \\
\text { results of the } \\
\text { baseline } \\
\text { assessment were } \\
\text { included in this } \\
\text { review }\end{array}$ & $\begin{array}{l}\text { To describe the } \\
\text { relationships between } \\
\text { daily activity with } \\
\text { clinical features and } \\
\text { standard HF } \\
\text { assessments (NYHA } \\
\text { class, 6MWD, HF QOL } \\
\text { scores and NT-proBNP) } \\
\text { at baseline and the } \\
\text { relationship between } \\
\text { changes in activity and } \\
\text { changes in standard HF } \\
\text { assessments with ISMN }\end{array}$ & $\begin{array}{l}\text { Patients were eligible for } \\
\text { study participation if they } \\
\text { had NYHA class II-IV } \\
\text { were at least } 50 \text { years of } \\
\text { age. They had preserved } \\
(\geq 50 \%) \text { EF who attributed } \\
\text { inactivity to HF-related } \\
\text { symptoms as assessed } \\
\text { using a screening } \\
\text { questionnaire. }\end{array}$ & $\begin{array}{l}\mathrm{N}=110 \\
\text { Mean age }=69 \\
\text { (SD not } \\
\text { reported), Male: } \\
\mathrm{N}=44(40 \%)\end{array}$ & $\begin{array}{l}\text { Participants in the group with the lower } \\
\text { daily accelerometer units were more } \\
\text { likely to have had HF hospitalisation, } \\
\text { orthopnea, diabetes and anaemia, be } \\
\text { treated with beta-blockers, have higher } \\
\text { EF, relative wall thickness and left atrial } \\
\text { volume and worse NYHA class, HF } \\
\text { specific quality of life (QOL) scores, } \\
\text { six-minute walk distance (6MWD) and } \\
\text { NT-proBNP (p<0.05 for all). }\end{array}$ \\
\hline
\end{tabular}




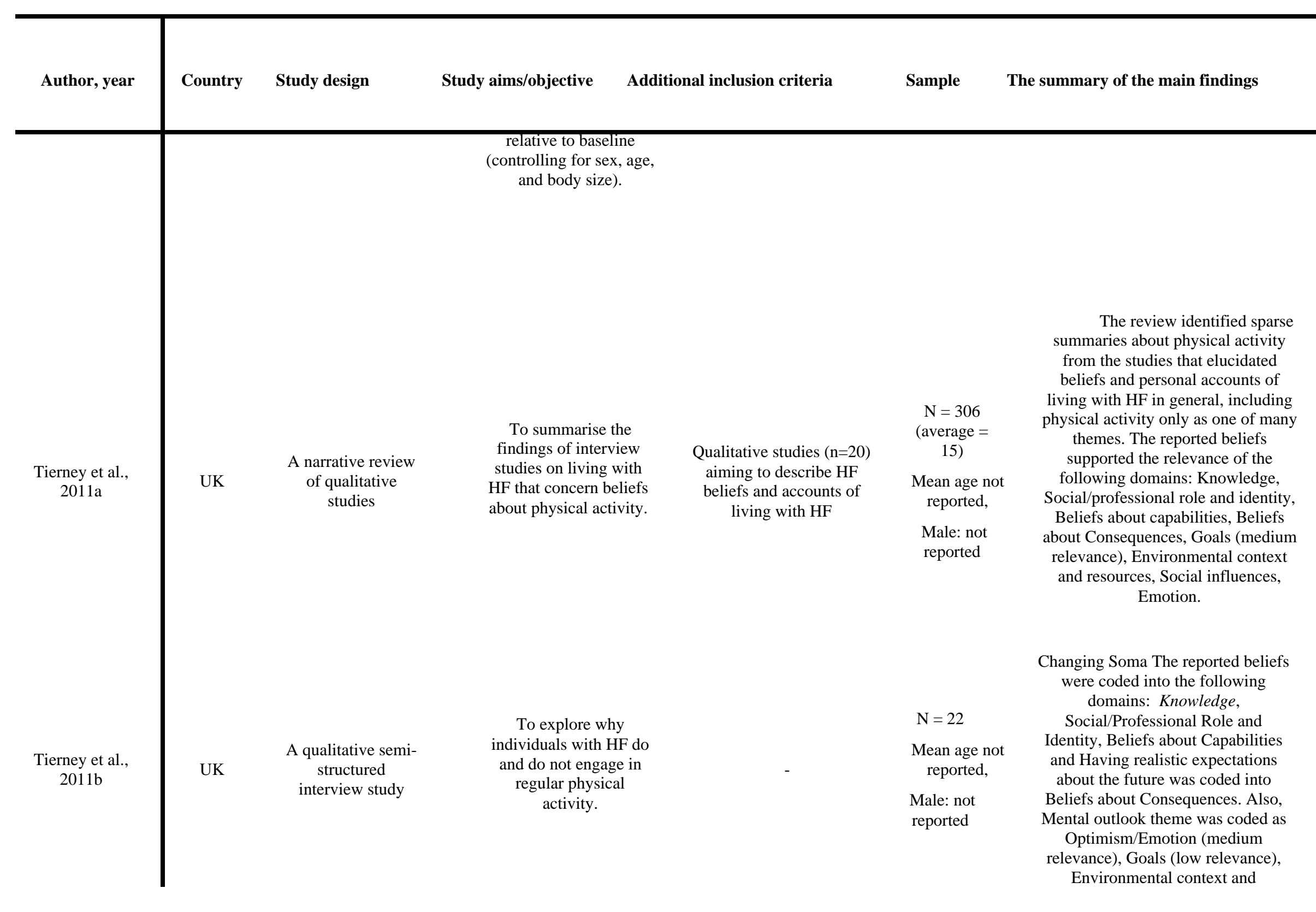




\begin{tabular}{|c|c|c|c|c|c|c|}
\hline Author, year & Country & Study design & Study aims/objective & Additional inclusion criteria & Sample & The summary of the main findings \\
\hline & & & & & & $\begin{array}{l}\text { resources, Social influences, } \\
\text { Intention (low relevance). }\end{array}$ \\
\hline $\begin{array}{l}\text { van der Wal et al., } \\
\text { 2006; } 2010\end{array}$ & Netherlands & $\begin{array}{l}\text { A baseline } \\
\text { assessment (cross- } \\
\text { sectional) from a } \\
\text { prospective study } \\
\text { investing clinical } \\
\text { outcomes }\end{array}$ & $\begin{array}{l}\text { To investigate the } \\
\text { association between } \\
\text { compliance with non- } \\
\text { pharmacological } \\
\text { recommendations (diet, } \\
\text { fluid restriction, } \\
\text { weighing, exercise) and } \\
\text { outcome in patients with } \\
\text { heart failure (HF). }\end{array}$ & - & $\begin{array}{l}\mathrm{N}=830 \\
\text { Mean age }=72 \\
(\mathrm{SD}=11) \\
\text { Male: } \mathrm{N}= \\
300.6(60 \%)\end{array}$ & $\begin{array}{l}\text { At baseline assessment, the } \\
\text { participants who did not adhere to the } \\
\text { exercise recommendation were older, } \\
\text { more likely to be female, and have } \\
\text { comorbid Atrial fibrillation, diabetes, } \\
\text { stroke, and previous HF admission. } \\
\text { Depressive symptoms and Knowledge } \\
\text { were negatively associated with } \\
\text { compliance to exercise } \\
\text { recommendation. }\end{array}$ \\
\hline $\begin{array}{l}\text { Werhahn et al., } \\
2019\end{array}$ & Germany & $\begin{array}{c}\text { A prospective } \\
\text { observational study } \\
\text { evaluating an } \\
\text { intervention; only } \\
\text { the results of the } \\
\text { baseline } \\
\text { assessment were } \\
\text { included in this } \\
\text { review }\end{array}$ & $\begin{array}{l}\text { To evaluate the } \\
\text { feasibility and usability } \\
\text { of A mobile application } \\
\text { designed to enhance } \\
\text { self-management. }\end{array}$ & Newly diagnosed HF & $\begin{array}{l}\quad \mathrm{N}=10 \\
\text { Mean age }= \\
46.3(\mathrm{SD}=7.8) \\
\text { Male: } \mathrm{N}=6 \\
(40 \%)\end{array}$ & $\begin{array}{l}\text { Everyday physical activity (the MDSC } \\
\text { captured by built-in pedometer } \\
\text { functions of smartphone and } \\
\text { smartwatch)averaged over } 14 \text { days } \\
\text { was low following hospital discharge } \\
\text { (3612 } \pm 3311) \text {, increased significantly } \\
\text { to the first follow-up ( } 6927 \pm 4871 ; \mathrm{P} \\
<0.0001) \text { and to the end of study } \\
\text { (7069 } \pm 5006 ; \mathrm{P}<0.0001) \\
\text { The MDSC correlated significantly } \\
\text { with exercise capacity parameters - } \\
\text { the distance in the conventional } \\
\text { 6MWT and peak VO2 in CPET. A } \\
\text { strong association with patient- } \\
\text { reported outcomes in the MLHFQ and } \\
\text { KCCQ, especially with the sub-scores } \\
\text { representing health-related QoL, HF } \\
\text { symptoms, and PA, was observed. }\end{array}$ \\
\hline
\end{tabular}




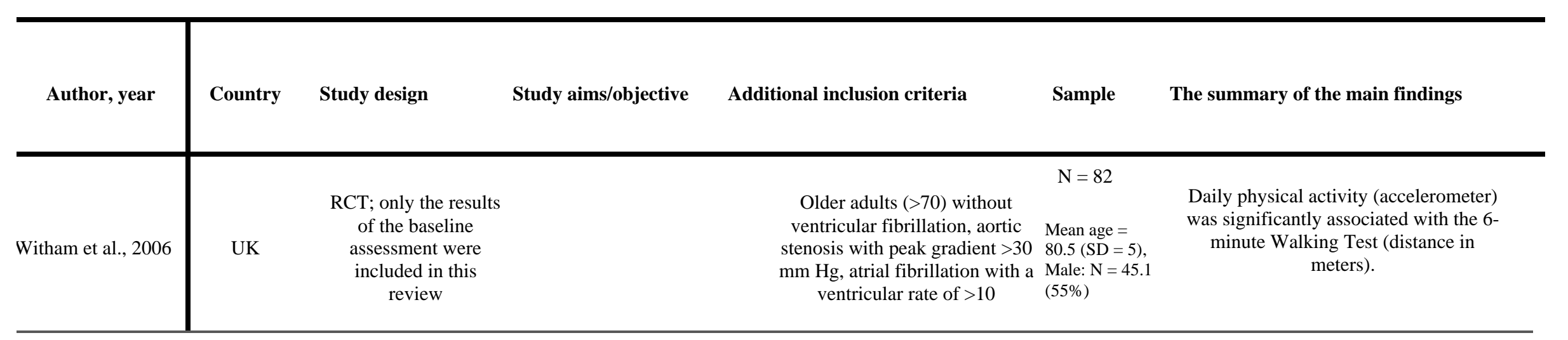

cross-sectional study $=$

7 (matched $=3$ ); baseline

assessment $($ RCT $)=4$;

Total number of studies: 19 prospective observational study

$=4($ matched $=1)$; qualitative

study $=2 ;$ narrative review $=1$. 
Table 2. Summary of the quantitative evidence, probability of physical activity conditioned on each identified construct according to quantitative evidence alone and qualitative and quantitative evidence combined.

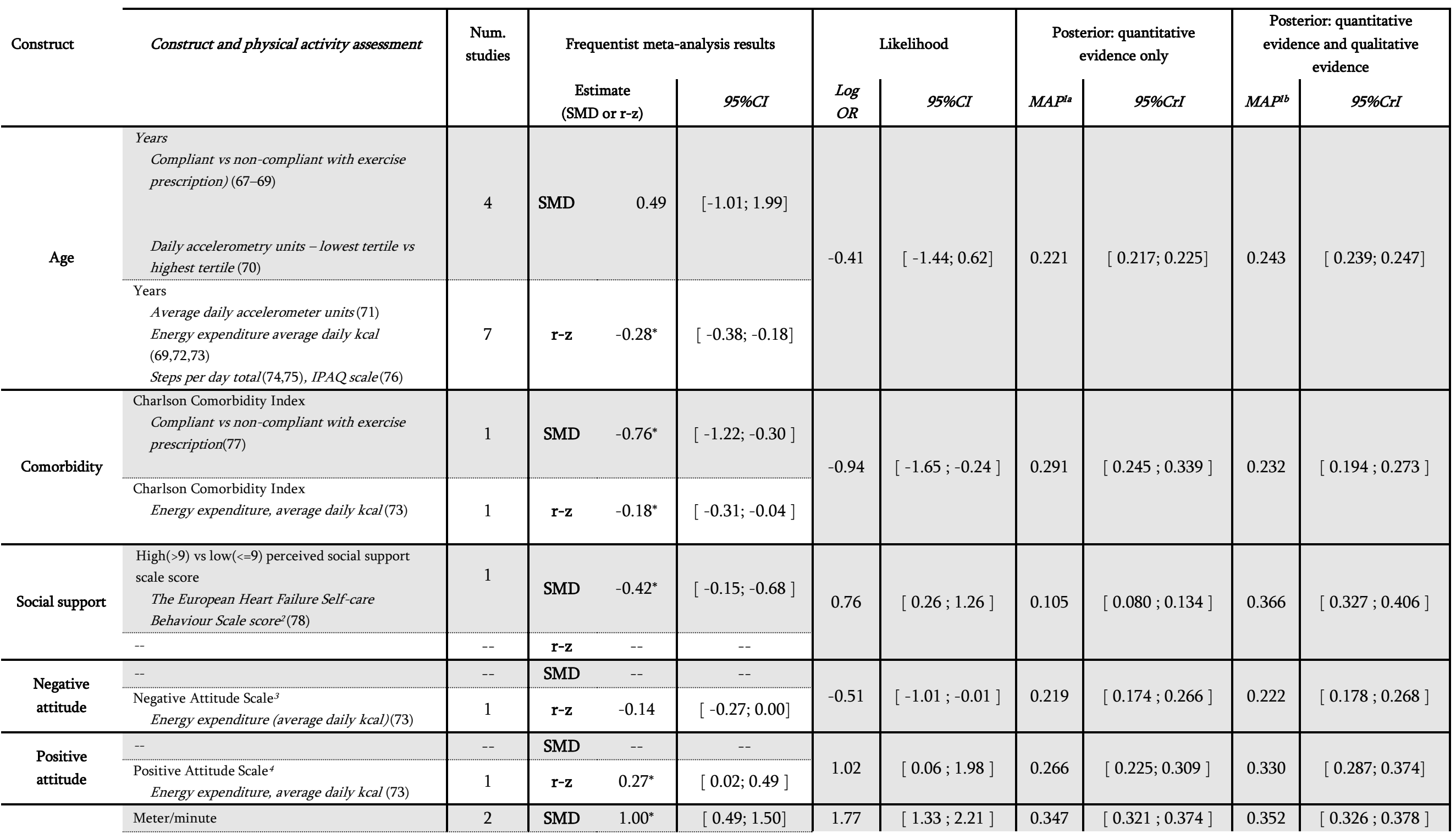




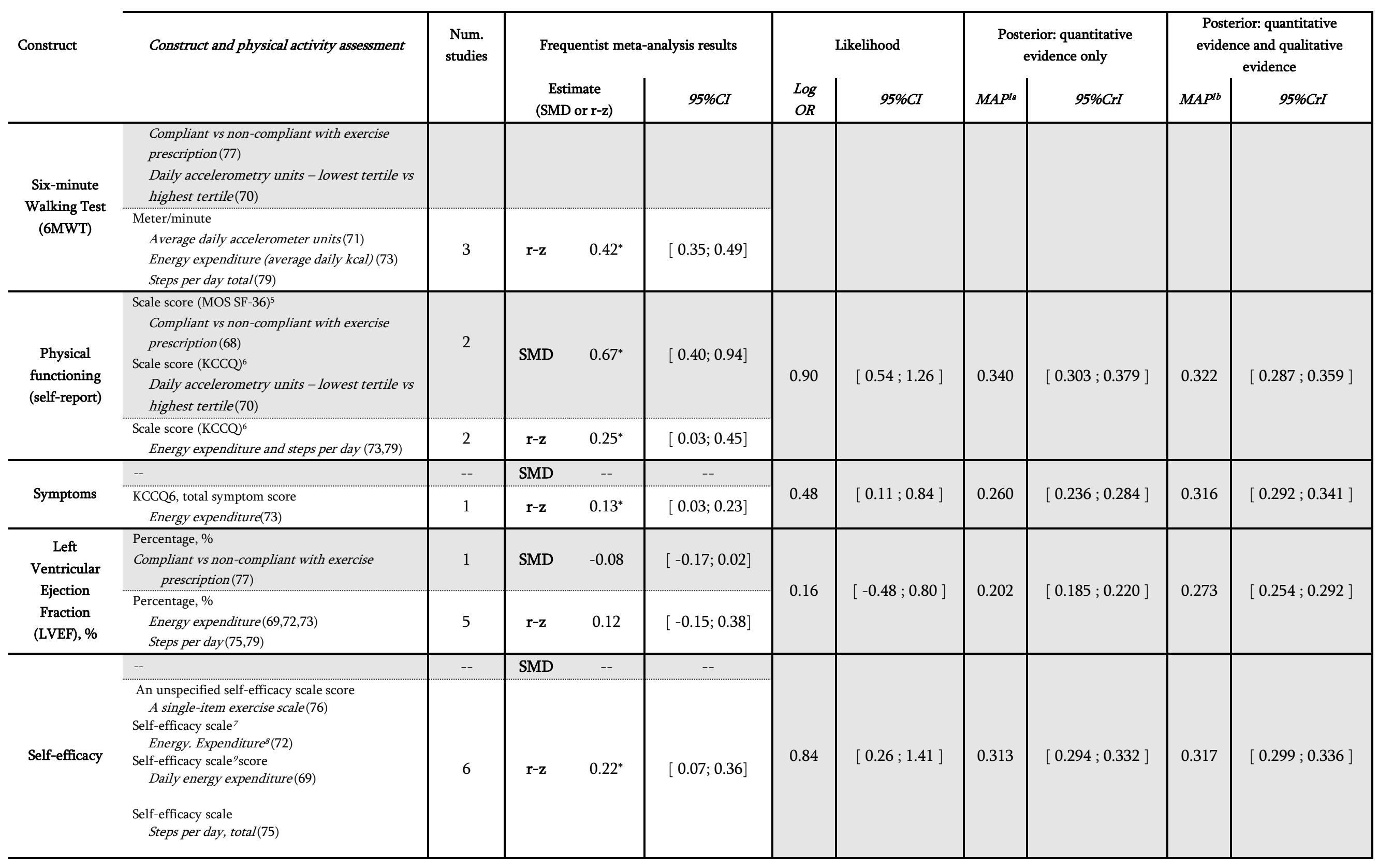




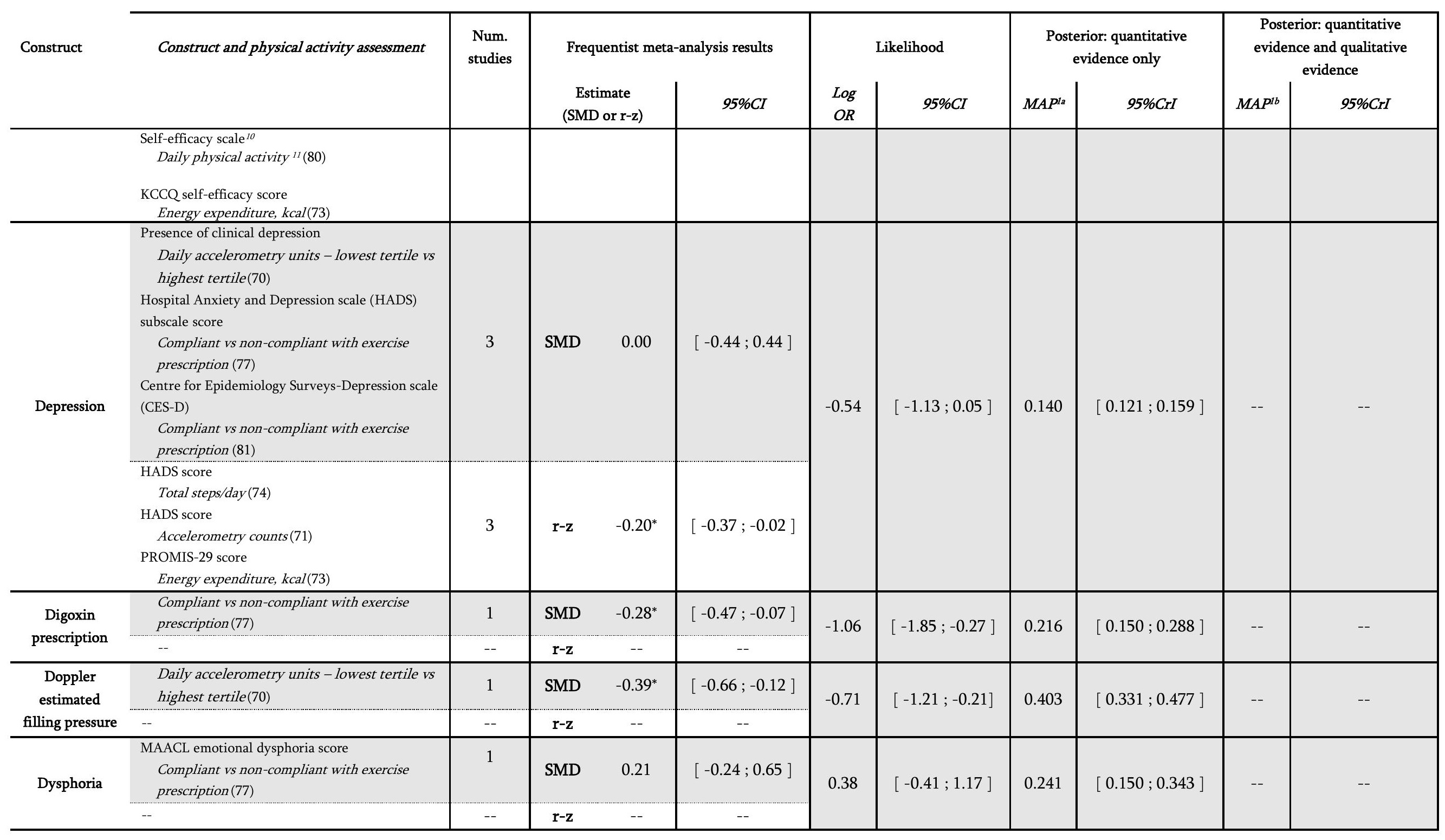




\begin{tabular}{|c|c|c|c|c|c|c|c|c|c|c|c|}
\hline \multirow[t]{2}{*}{ Construct } & \multirow[t]{2}{*}{ Construct and physical activity assessment } & \multirow[t]{2}{*}{$\begin{array}{l}\text { Num. } \\
\text { studies }\end{array}$} & \multicolumn{3}{|c|}{ Frequentist meta-analysis results } & \multicolumn{2}{|r|}{ Likelihood } & \multicolumn{2}{|c|}{$\begin{array}{l}\text { Posterior: quantitative } \\
\text { evidence only }\end{array}$} & \multicolumn{2}{|c|}{$\begin{array}{c}\text { Posterior: quantitative } \\
\text { evidence and qualitative } \\
\text { evidence }\end{array}$} \\
\hline & & & & $\begin{array}{l}\text { nate } \\
\text { or } r-z)\end{array}$ & $95 \% C I$ & $\begin{array}{l}\log \\
\text { OR }\end{array}$ & $95 \% C I$ & $M A P^{l a}$ & $95 \% C_{r} I$ & $M A P^{l b}$ & $95 \% C_{r I}$ \\
\hline \multirow[t]{2}{*}{ Education } & $\begin{array}{l}\text { Education above junior } \\
\text { Energy expenditure (69) } \\
\text { College or over } \\
\text { Energy expenditure MET/min/week(72) } \\
\text { College or over } \\
\quad \text { Compliance rate (68) } \\
\text { Post-secondary degree } \\
\text { Energy expenditure, } \mathrm{kcal} \text { (73) }\end{array}$ & 4 & SMD & 0.06 & {$[-0.15 ; 0.27]$} & \multirow[t]{2}{*}{0.17} & \multirow[t]{2}{*}[-0.15;0.49]{} & \multirow[t]{2}{*}{0.288} & \multirow[t]{2}{*}[0.266;0.310]{} & \multirow[t]{2}{*}{--} & \multirow[t]{2}{*}{--} \\
\hline & $\begin{array}{l}\text { Years } \\
\quad \text { Accelerometer, steps per day (74) }\end{array}$ & 1 & $\mathbf{r}-\mathbf{z}$ & -0.06 & {$[-0.24 ; 0.12]$} & & & & & & \\
\hline \multirow[t]{2}{*}{ Employment } & $\begin{array}{l}\text { Yes vs no } \\
\quad \text { Energy expenditure }(72,73)\end{array}$ & 2 & SMD & $-0.43^{*}$ & {$[-0.82 ;-0.05]$} & \multirow[t]{2}{*}{-0.21} & \multirow[t]{2}{*}[-1.33;0.91]{} & \multirow[t]{2}{*}{0.215} & \multirow[t]{2}{*}[0.179;0.253]{} & \multirow[t]{2}{*}{--} & \multirow[t]{2}{*}{--} \\
\hline & -- & -- & $r-z$ & -- & -- & & & & & & \\
\hline \multirow[t]{2}{*}{ Ethnicity } & $\begin{array}{l}\text { Caucasian vs non-Caucasian } \\
\text { Daily accelerometry units - lowest tertile vs } \\
\text { highest tertile (70) } \\
\text { Energy expenditure (73) }\end{array}$ & 2 & SMD & 0.22 & {$[-0.10 ; 0.54]$} & \multirow[t]{2}{*}{0.34} & \multirow[t]{2}{*}[-0.07;0.75]{} & \multirow[t]{2}{*}{0.280} & \multirow[t]{2}{*}[0.248;0.312]{} & \multirow[t]{2}{*}{--} & \multirow[t]{2}{*}{--} \\
\hline & -- & -- & r-z & -- & -- & & & & & & \\
\hline \multirow[t]{2}{*}{ HF duration } & $\begin{array}{l}\text { Years } \\
\text { Compliant vs non-compliant with exercise } \\
\text { prescription (77) }\end{array}$ & $\begin{array}{l}1 \\
--\end{array}$ & SMD & $-0.66^{*}$ & {$[-1.11 ;-0.20]$} & \multirow[t]{2}{*}{-0.95} & \multirow[t]{2}{*}[-1.48;-0.42]{} & \multirow[t]{2}{*}{0.283} & \multirow[t]{2}{*}[0.227;0.341]{} & \multirow[t]{2}{*}{--} & \multirow[t]{2}{*}{--} \\
\hline & $\begin{array}{l}\text { Years } \\
\quad \text { Energy expenditure total(72) }\end{array}$ & 1 & $\mathrm{r}-\mathbf{z}$ & $-0.20^{*}$ & {$[-0.37 ;-0.02]$} & & & & & & \\
\hline HFrEF (Yes) & $\begin{array}{l}\text { HFrEF vs HFpEF } \\
\quad \text { Energy expenditure, kcal(73) }\end{array}$ & 1 & SMD & 0.00 & {$[-0.19 ; 0.19]$} & -0.22 & {$[-1.01 ; 0.57]$} & 0.399 & {$[0.345 ; 0.454]$} & -- & -- \\
\hline & -- & -- & $\mathrm{r}-\mathrm{z}$ & - & -- & & & & & & \\
\hline & -- & - & SMD & -- & - & & & & & - & - \\
\hline pro-BNP & $\begin{array}{l}\mathrm{ng} / \mathrm{mL} \\
\text { Duration, hours/day }(79)\end{array}$ & 1 & $\mathrm{r}-\mathbf{z}$ & 0.37 & {$[-0.34 ; 0.81]$} & -1.16 & {$[-1.52 ;-0.80]$} & 0.142 & {$[0.094 ; 0.197]$} & & \\
\hline Hostility & $\begin{array}{l}\text { MAACL hostility score } \\
\text { Compliant vs non-compliant with exercise } \\
\text { prescription (77) }\end{array}$ & 1 & SMD & 0.43 & {$[-0.02 ; 0.88]$} & 0.79 & {$[0.00 ; 1.58]$} & 0.241 & {$[0.150 ; 0.343]$} & -- & -- \\
\hline & & -- & r-z & -- & -- & & & & & & \\
\hline
\end{tabular}




\begin{tabular}{|c|c|c|c|c|c|c|c|c|c|c|c|}
\hline \multirow[t]{2}{*}{ Construct } & \multirow[t]{2}{*}{ Construct and physical activity assessment } & \multirow[t]{2}{*}{$\begin{array}{l}\text { Num. } \\
\text { studies }\end{array}$} & \multicolumn{3}{|c|}{ Frequentist meta-analysis results } & \multicolumn{2}{|r|}{ Likelihood } & \multicolumn{2}{|c|}{$\begin{array}{l}\text { Posterior: quantitative } \\
\text { evidence only }\end{array}$} & \multicolumn{2}{|c|}{$\begin{array}{c}\text { Posterior: quantitative } \\
\text { evidence and qualitative } \\
\text { evidence }\end{array}$} \\
\hline & & & \multicolumn{2}{|c|}{$\begin{array}{l}\text { Estimate } \\
\text { (SMD or r-z) }\end{array}$} & \multirow{2}{*}{$\frac{95 \% C I}{--}$} & $\begin{array}{l}\log \\
\text { OR }\end{array}$ & $95 \% C I$ & $M A P^{l a}$ & $95 \% C_{r} I$ & $M A P^{l b}$ & $95 \% C_{r I}$ \\
\hline & -- & -- & SMD & -- & & \multirow[b]{2}{*}{0.18} & \multirow[b]{2}{*}[-0.44;0.80]{} & \multirow[b]{2}{*}{0.252} & \multirow[b]{2}{*}[0.192;0.317]{} & \multirow[b]{2}{*}{--} & \multirow[b]{2}{*}{--} \\
\hline Income & $\begin{array}{l}\text { Above poverty } \\
\text { Energy expenditure (72) }\end{array}$ & 1 & $\mathbf{r}-\mathbf{z}$ & 0.05 & {$[-0.13 ; 0.23]$} & & & & & & \\
\hline \multirow{2}{*}{$\begin{array}{c}\text { Left Atrial } \\
\text { Volume index } \\
\quad(\mathrm{LAV})\end{array}$} & $\begin{array}{l}1 / \mathrm{m} 2 \\
\text { Daily accelerometry units - lowest tertile vs } \\
\text { highest tertile(70) }\end{array}$ & 1 & SMD & $-0.61^{*}$ & {$[-0.88 ;-0.34]$} & \multirow[t]{2}{*}{-1.12} & \multirow[t]{2}{*}[-1.62;-0.62]{} & \multirow[t]{2}{*}{0.150} & \multirow[t]{2}{*}[0.101;0.206]{} & \multirow[t]{2}{*}{--} & \multirow[t]{2}{*}{--} \\
\hline & -- & -- & $\mathbf{r}-\mathbf{z}$ & -- & -- & & & & & & \\
\hline \multirow{2}{*}{$\begin{array}{c}\text { Left } \\
\text { Ventricular } \\
\text { Assist Device } \\
\text { (LVAD) } \\
\end{array}$} & $\begin{array}{l}\text { Pre-post LVAD } \\
\quad \text { Energy expenditure total (82) }\end{array}$ & 1 & SMD & $1.08^{*}$ & {$[0.55 ; 1.60]$} & \multirow{2}{*}{1.98} & \multirow{2}{*}[1.04;2.92]{} & \multirow{2}{*}{0.385} & \multirow{2}{*}[0.325;0.446]{} & \multirow[b]{2}{*}{--} & \multirow{2}{*}{--} \\
\hline & -- & -- & $\mathbf{r}-\mathbf{z}$ & -- & -- & & & & & & \\
\hline \multirow{2}{*}{$\begin{array}{c}\text { Left } \\
\text { Ventricular } \\
\text { Remodelling } \\
\text { (LVR) }\end{array}$} & $\begin{array}{l}\text { Relative myocardial wall thickness } \\
\text { Daily accelerometry units - lowest tertile vs } \\
\text { highest tertile(70) }\end{array}$ & 1 & SMD & -0.11 & {$[-0.37 ; 0.16]$} & \multirow[t]{2}{*}{-0.20} & \multirow[t]{2}{*}[-0.70;0.30]{} & \multirow[t]{2}{*}{0.313} & \multirow[t]{2}{*}[0.246;0.384]{} & -- & -- \\
\hline & -- & & $\mathbf{r}-\mathbf{z}$ & -- & -- & & & & & & \\
\hline Partner & $\begin{array}{l}\text { Living with a spouse, Yes vs No } \\
\text { Daily energy expenditure (69) } \\
\text { Marital status } \\
\text { Compliance rate (68) }\end{array}$ & 2 & SMD & $-0.50^{*}$ & {$[-0.92 ;-0.08]$} & -0.46 & {$[-1.36 ; 0.44]$} & 0.297 & {$[0.273 ; 0.322]$} & -- & -- \\
\hline & -- & -- & $\mathrm{r}-\mathbf{z}$ & -- & -- & & & & & & \\
\hline PeakVO2 & $\begin{array}{l}\mathrm{mL} / \mathrm{kg} / \mathrm{min} \\
\text { Compliant vs non-compliant with exercise } \\
\text { prescription (77) }\end{array}$ & 1 & SMD & $0.79^{*}$ & {$[0.33 ; 1.25]$} & 1.54 & {$[0.71 ; 2.37$ ] } & 0.283 & {$[0.193 ; 0.380]$} & -- & -- \\
\hline & $\begin{array}{l}\mathrm{mL} / \mathrm{kg} / \mathrm{min} \\
\text { Steps/day, total (79) }\end{array}$ & 1 & $\mathbf{r}-\mathbf{z}$ & 0.57 & {$[-0.09 ; 0.88]$} & & & & & & \\
\hline Perceived & -- & -- & SMD & -- & -- & & & & & & \\
\hline exertion & IPAQ scale (80) & 1 & $\mathrm{r}-\mathrm{z}$ & -0.26 & {$[-0.52 ; 0.04]$} & -0.98 & {$[-2.10 ; 0.14]$} & 0.313 & {$[0.216 ; 0.419]$} & -- & -- \\
\hline Quality of Life & $\begin{array}{l}\text { KCCQ scale }{ }^{6} \text { total score } \\
\text { Daily accelerometry units - lowest tertile vs } \\
\text { highest tertile }(70)\end{array}$ & 1 & SMD & $0.47^{*}$ & {$[0.33 ; 0.60]$} & 0.51 & {$[0.11 ; 0.92$ ] } & 0.243 & {$[0.221 ; 0.266]$} & -- & -- \\
\hline (QoL) & $\begin{array}{l}\text { KCCQ scale }{ }^{5} \text { total score } \\
\text { Energy expenditure }(72,73)\end{array}$ & 2 & $\mathbf{r}-\mathbf{z}$ & 0.01 & {$[-0.17 ; 0.18]$} & & & & & & \\
\hline
\end{tabular}




\begin{tabular}{|c|c|c|c|c|c|c|c|c|c|c|c|}
\hline \multirow[t]{2}{*}{ Construct } & \multirow[t]{2}{*}{ Construct and physical activity assessment } & \multirow[t]{2}{*}{$\begin{array}{l}\text { Num. } \\
\text { studies }\end{array}$} & \multicolumn{3}{|c|}{ Frequentist meta-analysis results } & \multicolumn{2}{|r|}{ Likelihood } & \multicolumn{2}{|c|}{$\begin{array}{l}\text { Posterior: quantitative } \\
\text { evidence only }\end{array}$} & \multicolumn{2}{|c|}{$\begin{array}{c}\text { Posterior: quantitative } \\
\text { evidence and qualitative } \\
\text { evidence }\end{array}$} \\
\hline & & & & & $95 \% C I$ & $\begin{array}{l}\log \\
O R \\
\end{array}$ & $95 \% C I$ & $M A P^{l a}$ & $95 \% C r I$ & $M A P^{l b}$ & $95 \% C_{r I}$ \\
\hline \multirow[t]{2}{*}{ Renal function } & $\begin{array}{l}\text { Estimated glomerular filtration rate (eGFR) } \\
\mathrm{ml} / \text { min } \\
\text { Accelerometer units lowest tertile vs highest } \\
\text { tertile( } 70)\end{array}$ & 1 & SMI & $0.59^{*}$ & {$[0.32 ; 0.86]$} & \multirow[t]{2}{*}{1.07} & \multirow[t]{2}{*}[0.57;1.57]{} & \multirow[t]{2}{*}{0.216} & \multirow[t]{2}{*}[0.157;0.279]{} & \multirow[t]{2}{*}{--} & \multirow[t]{2}{*}{-- } \\
\hline & -- & -- & $\mathrm{r}-\mathrm{z}$ & -- & -- & & & & & & \\
\hline \multirow[b]{2}{*}{ Smoking } & -- & -- & SMI & -- & -- & \multirow[b]{2}{*}{0.66} & \multirow[b]{2}{*}[-0.05;1.37]{} & \multirow[b]{2}{*}{0.307} & \multirow[b]{2}{*}[0.242;0.375]{} & \multirow[b]{2}{*}{--} & \multirow[b]{2}{*}{--} \\
\hline & $\begin{array}{l}\text { Smoking (yes vs no) } \\
\text { Energy expenditure(72) }\end{array}$ & 1 & $\mathbf{r}-\mathbf{z}$ & 0.18 & {$[-0.01 ; 0.35]$} & & & & & & \\
\hline Symptom & - & -- & SMI & -- & -- & \multirow{2}{*}{-0.46} & \multirow{2}{*}[-0.82;-0.10]{} & \multirow{2}{*}{0.211} & \multirow{2}{*}{$0.181 ; 0.243$ ] } & \multirow{2}{*}{--} & \multirow{2}{*}{--} \\
\hline distress & MSAS-SF ${ }^{12}$ Energy expenditure, total daily (69) & 1 & $\mathbf{r}-\mathbf{z}$ & $-0.13^{*}$ & {$[-0.22 ;-0.03]$} & & & & & & \\
\hline
\end{tabular}

Note. Construct definitions are from the om APA dictionary, NICE (HF), TDF. MAP -Maximum a posteriori probability estimate. The expert-elicited prior distribution is summarised as MAP (Credible Interval), the Beta distribution's shape parameters $(\beta, œ)$. The difference in MAP between physical activity in HF (general) and when it is updated with the probability of physical activity conditioned on each construct as informed by the prior elicitation task. Probability of physical activity in HF in general: $\operatorname{Pr}(\operatorname{PA} \mid \mathrm{HF})=0.32$. The likelihood summarises quantitative evidence as SMD in physical activity $(95 \%$ CI) between the exposure and control groups; or SMD (95\% CI) in physical activity for two categories (e.g. age 70 vs age <70 years old), or SMD (95\% CI) in the construct between those meeting the exercise recommendation (compliant) and those not (non-compliant); or/and r-z coefficient (95\% CI) for the association between PA and the construct. 1a. MAP summarising the posterior distribution elicited by updating the probability of physical activity in the general $\mathrm{HF}$ population $(\mathrm{Pr}(\mathrm{PA} \mid \mathrm{HF})=0.32)$ with quantitative evidence only. $1 \mathrm{~b}$. MAP summarising the posterior distribution elicited by updating the probability of physical activity in HF population $(\operatorname{Pr}(\mathrm{PA} \mid \mathrm{HF})=0.32)$ with quantitative and qualitative evidence. 2 . The European Heart Failure Self-care Behaviour scale (83). 3. Negative attitude towards physical activity (subscale) (84). 4. Positive attitude towards physical activity (subscale) (84). 5. MOS SF-36 (85). 6. KCCQ - The Kansas City Cardiomyopathy

Questionnaire (86). 7. Self-efficacy scale (87). 8. Physical activity in patients scale (88). 9. The Self-efficacy for Physical Activity Scale (89). 10. Self-efficacy scale (87)(Jenkins et al., 1994) 11. Duke Physical activity Index (90). 12. MSAS-SF - The Memorial Symptom Assessment Scale Short Form (91). 
Table 3. Summary of the barriers and enablers suggested by qualitative and quantitative evidence and proposed behaviour change techniques (BCTs).

\begin{tabular}{|c|c|c|c|c|c|c|}
\hline Construct $^{1}$ & TDF domain & $\begin{array}{l}\text { Mechanisms of Action } \\
\text { (MoAs) }\end{array}$ & Type of evidence & $\begin{array}{l}\text { Uncertainty } \\
\text { in the } \\
\text { evidence }^{2}\end{array}$ & Proposed behaviour change techniques (BCTTv1) & COM-B \\
\hline \multicolumn{7}{|c|}{ CONTEXTUAL BARRIERS } \\
\hline Older age $(>70$ years old $)$ & - & - & qual and QUANT & low & - & $\begin{array}{c}\text { Psychological } \\
\text { Capability, Physical } \\
\text { Capability }\end{array}$ \\
\hline low $L V E F(<30 \%)$ & - & - & QUANT & moderate & - & Physical Capability \\
\hline Depression & - & - & QUANT & high & - & $\begin{array}{l}\text { Automatic } \\
\text { Motivation }\end{array}$ \\
\hline \multicolumn{7}{|c|}{ MODIFIABLE BARRIERS AND ENABLERS } \\
\hline Beliefs about ageing & $\begin{array}{c}\text { Beliefs about } \\
\text { Capabilities }\end{array}$ & $\begin{array}{l}\text { Beliefs about } \\
\text { Capabilities }\end{array}$ & qual & high & $\begin{array}{l}\text { Behavioural practice and Rehearsal, Graded tasks, Social } \\
\text { comparison, Focus on past success, Verbal persuasion } \\
\text { about capability }\end{array}$ & \\
\hline Social role/self-identity & $\begin{array}{c}\text { Social, Professional } \\
\text { Role and Identity }\end{array}$ & Self-image & qual & high & $\begin{array}{l}\text { Identity associated with changed behavior, Reframing, } \\
\text { Cognitive dissonance }\end{array}$ & Reflective Motivation \\
\hline Local environment & $\begin{array}{c}\text { Environmental } \\
\text { Context and } \\
\text { Resources } \\
\end{array}$ & $\begin{array}{l}\text { Environmental Context } \\
\text { and Resources }\end{array}$ & qual & high & $\begin{array}{l}\text { Adding objects to the environment, Prompts/cues, } \\
\text { Avoidance/changing exposure to cues for the behaviour }\end{array}$ & Physical Opportunity \\
\hline Social support & Social Influences & Social Influences & $\begin{array}{c}\text { qual and QUANT } \\
\text { (contradictory) }\end{array}$ & high & $\begin{array}{c}\text { Social support (unspecified), Social support (emotional), } \\
\text { (Social support practical) }\end{array}$ & Social Opportunity \\
\hline Outcome expectancies & $\begin{array}{l}\text { Beliefs about } \\
\text { Consequences }\end{array}$ & $\begin{array}{l}\text { Beliefs about } \\
\text { Consequences }\end{array}$ & qual & high & $\begin{array}{c}\text { Information about consequences, Salience of } \\
\text { consequences, Feedback on behaviour, Feedback on the } \\
\text { outcome of behaviour, Pros and cons, Emotional } \\
\text { consequences, Covert sensitisation, Anticipated regret, } \\
\text { Comparative imagining of future outcomes, Vicarious } \\
\text { reinforcement }\end{array}$ & Reflective Motivation \\
\hline Self-efficacy & $\begin{array}{l}\text { Beliefs about } \\
\text { Capabilities }\end{array}$ & $\begin{array}{l}\text { Beliefs about } \\
\text { Capabilities }\end{array}$ & $\begin{array}{c}\text { qual and } \\
\text { QUANT(contradi } \\
\text { ctory) }\end{array}$ & high & $\begin{array}{c}\text { Behavioural practice and Rehearsal, Graded tasks, } \\
\text { Social comparison, Focus on past success, Verbal } \\
\text { persuasion about capability } \\
\end{array}$ & Reflective motivation \\
\hline Problem solving & $\begin{array}{l}\text { Behavioural } \\
\text { Regulation }\end{array}$ & Behavioural Regulation & qual & high & $\begin{array}{c}\text { Action planning, Self-monitoring behaviour, Problem } \\
\text { solving, Goal setting outcome, Feedback on behaviour, } \\
\text { Habit formation }\end{array}$ & $\begin{array}{l}\text { Psychological } \\
\text { Capability }\end{array}$ \\
\hline
\end{tabular}




\begin{tabular}{|c|c|c|c|c|c|c|}
\hline Negative attitude & Emotion/Optimism & Emotion & qual and QUANT & high & $\begin{array}{c}\text { Reduce negative emotions, Information about health } \\
\text { consequences, Information about emotional } \\
\text { consequences }\end{array}$ & $\begin{array}{l}\text { Automatic } \\
\text { Motivation }\end{array}$ \\
\hline Positive attitude & $\begin{array}{l}\text { Beliefs about } \\
\text { Consequences }\end{array}$ & $\begin{array}{l}\text { Attitude towards the } \\
\text { behaviour }\end{array}$ & 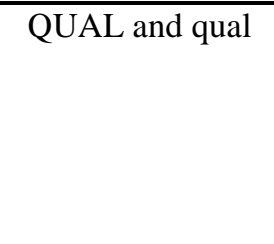 & high & $\begin{array}{c}\text { Information about consequences, Salience of } \\
\text { consequences, Feedback on behaviour, Feedback on the } \\
\text { outcome of behaviour, Pros and cons, Emotional } \\
\text { consequences, Covert sensitisation, Anticipated regret, } \\
\text { Comparative imagining of future outcomes, Vicarious } \\
\text { reinforcement }\end{array}$ & Reflective Motivation \\
\hline
\end{tabular}




\section{STEP 1}

An empirical hyperprior was obtained from the secondary analysis of studies across 15 countries reported by Jaarsma et al. (15).
The probability of physical activity conditioned on a barrier or an enabler was estimated relative to the low probability of physical activity in HF, which is considerably lower than in general population (15). An empirical hyperprior describing probability of physical activity in HF was obtained from the secondary analysis of studies across 15 countries reported by Jaarsma et al. (15).

Three reviewers (AA, AC, BV) independently, line-by-line, annotated the qualitative studies' result section using the Theoretical Domains Framework, TDF (37). The coding agreement was high (AA vs AC: $87 \%$; AA vs BV: $76 \%$; BV vs AC: $86 \%$ ). The descriptions of the important influences on physical activity in HF provided by the authors of the included qualitative studies were annotated using TDF. These descriptions were compared to the definitions of various psychosocial constructs from the TDF, APA dictionary (92), and NICE HF guidelines (93).

A prior elicitation task $(62,94,95)$ was developed to capture experts' beliefs about the probability distribution for physical activity conditioned on the constructs identified relevant in qualitative evidence (i.e. informative prior), The task asked the experts to share their belief about the probability of physical activity in 30 scenarios. The scenarios illustrated hypothetical HF patients. The 30 hypothetical HF patients were described to either display a construct or not in three sets of combinations of the constructs identified in qualitative studies. Six reviewers (AA; LT; BV; NA; AC; AT) completed the expert elicitation task.

The association between physical activity and determinants assessed in quantitative studies were summarised in a meta-analysis including univariate associations using a random-effect model with maximum likelihood estimation (REML). The bivariate correlation (Pearson's $r$ coefficient, unadjusted) between physical activity and an associated variable and the standardised mean differences $(S M D)$ between groups in the dichotomised assessment were summarised in a pooled estimate, separately. The meta-analyses were implemented in $\mathrm{R}$ using the metafor library (96). The sampling distribution variance was standardised using an $r-z$ transformation. This was done to mitigate heterogeneity in the measurement of the outcome. SMD between exposure and control was estimated for the same reason.

\section{STEP 4}

Bayesian analysis elicited the probability of physical activity conditioned on a barrier/enabler when both qualitative and quantitative evidence is considered (i.e., posterior).

Evidence evaluation for each barrier or enabler using Bayesian analysis is described in Figure 2. Depending on the availability of the evidence we followed either procedure 1, 2, or 3, and synthesised QUAL + quant; or quant evidence only, following methods described by Roberts et al.(35) Detailed statistical analysis is reported in supplement 3 .
Figure 1. Statistical analysis.
Note 1. QUNT indicates that the majority of the evidence $(n=16)$ was quantitative, and qual indicates that only three studies were qualitative. 
medRxiv preprint doi: https://doi.org/10.1101/2021.09.05.21262643; this version posted September 8, 2021. The copyright holder for this preprint (which was not certified by peer review) is the author/funder, who has granted medRxiv a license to display the preprint in It is made available under a CC-BY-NC 4.0 International license. 


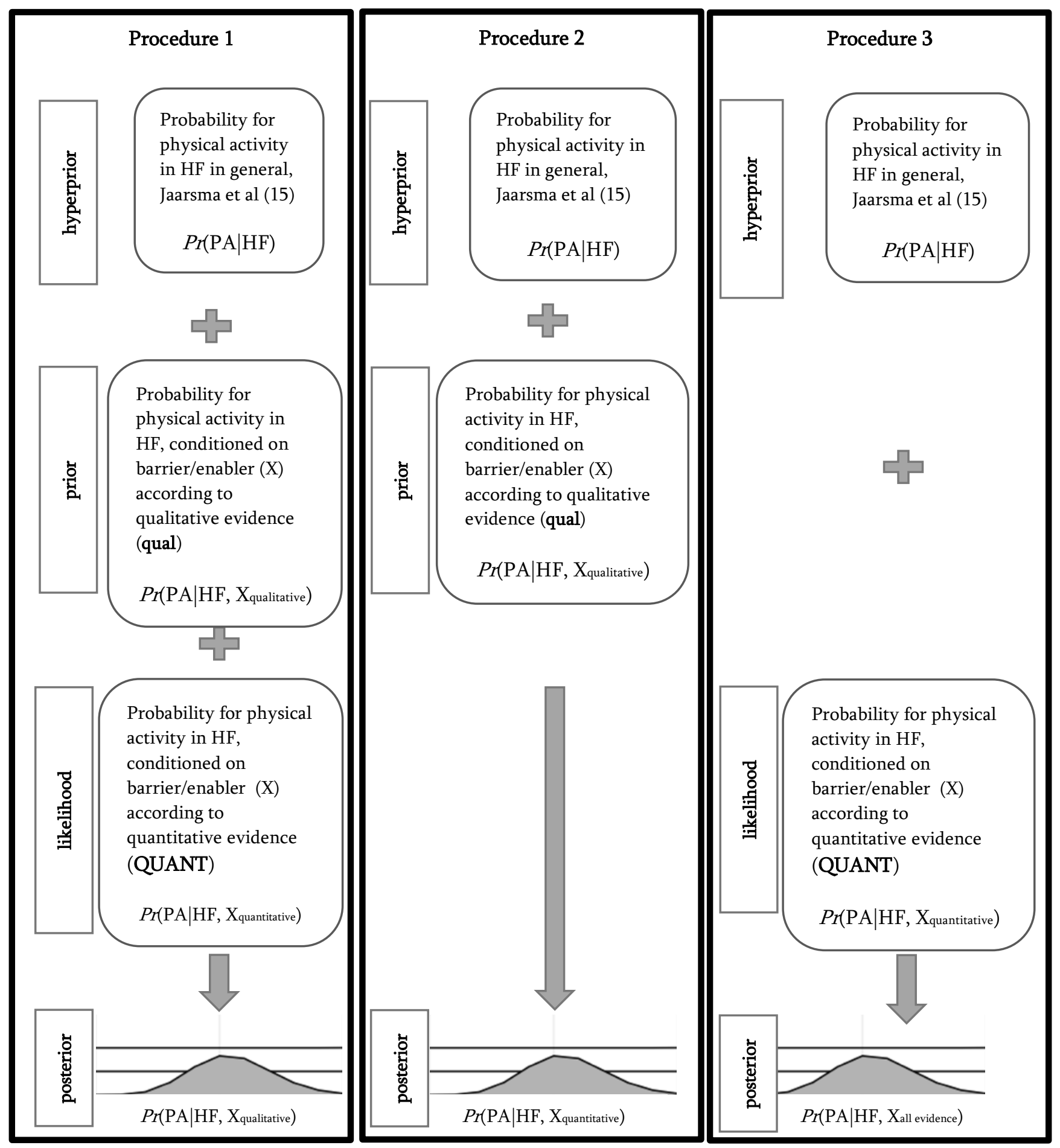

Figure 2. Evidence evaluation for each barrier or enabler: Bayesian meta-analysis combing qual and QUANT; or QUANT evidence only. Depending on the availability of the evidence, either procedure 1, 2, or 3 was followed. 
medRxiv preprint doi: https://doi.org/10.1101/2021.09.05.21262643; this version posted September 8, 2021. The copyright holder for this preprint (which was not certified by peer review) is the author/funder, who has granted medRxiv a license to display the preprint in It is made available under a CC-BY-NC 4.0 International license .

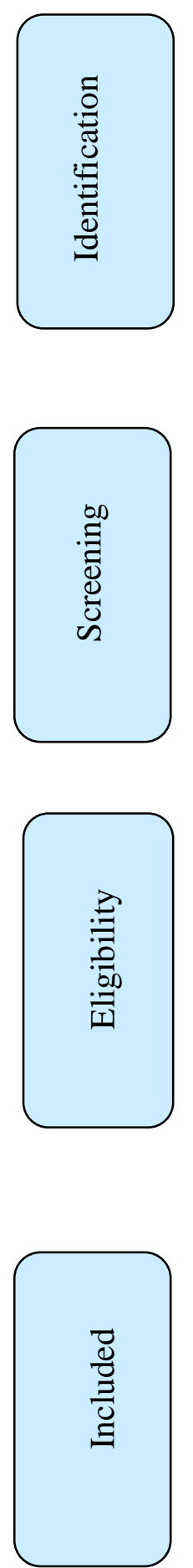

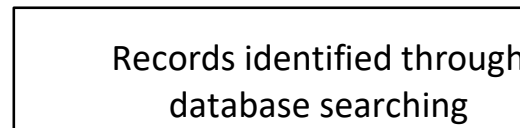

$(n=9282)$

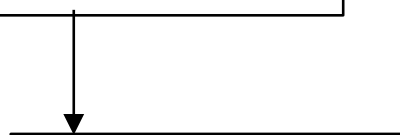

Additional records identified through other sources $(n=0)$

Records after duplicates removed

$(n=9026)$

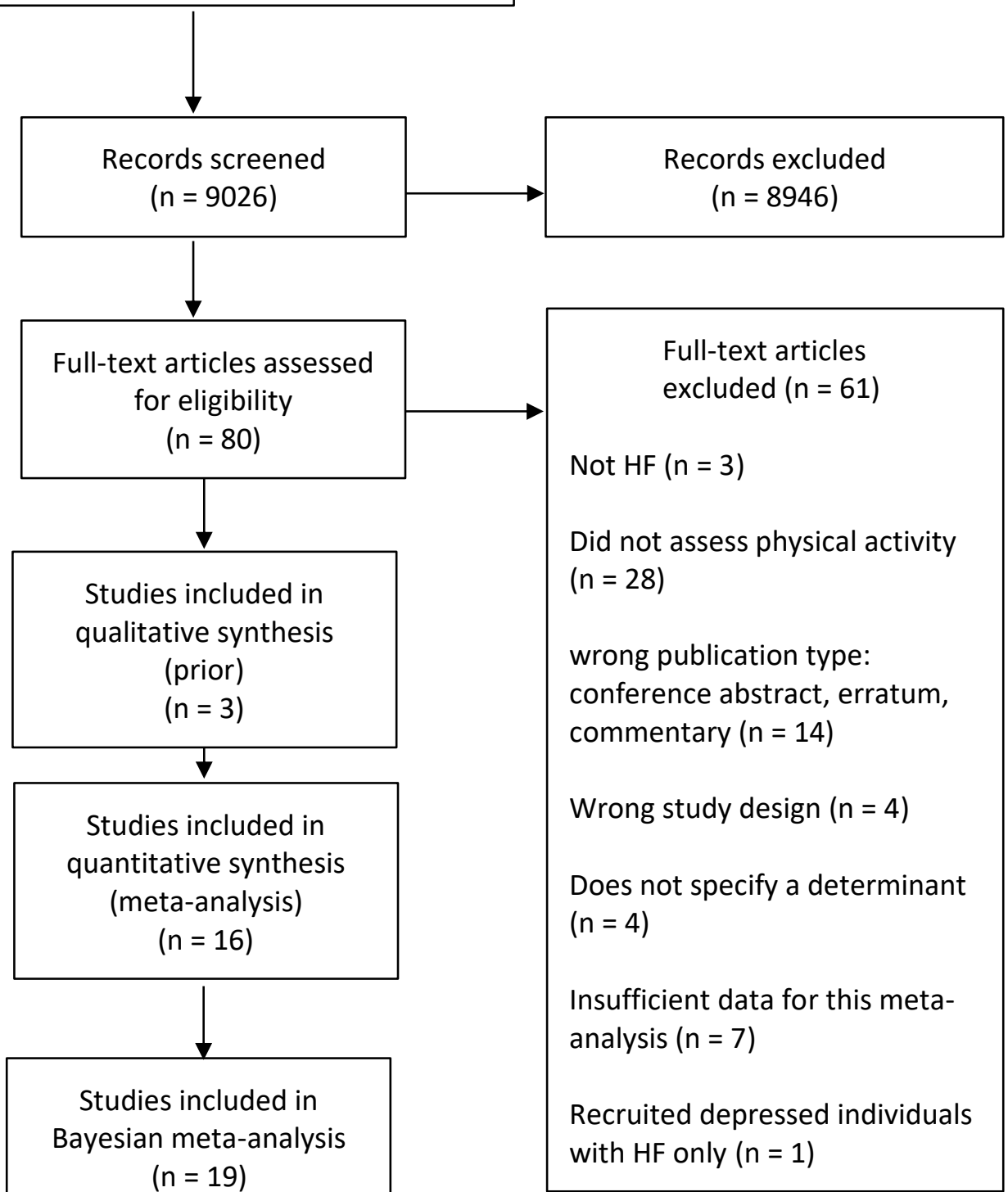

Figure 3. Meta-analysis of barriers and enablers of physical activity in HF: PRISMA diagram 
medRxiv preprint doi: https://doi.org/10.1101/2021.09.05.21262643; this version posted September 8, 2021. The copyright holder for this preprint (which was not certified by peer review) is the author/funder, who has granted medRxiv a license to display the preprint in It is made available under a CC-BY-NC 4.0 International license .

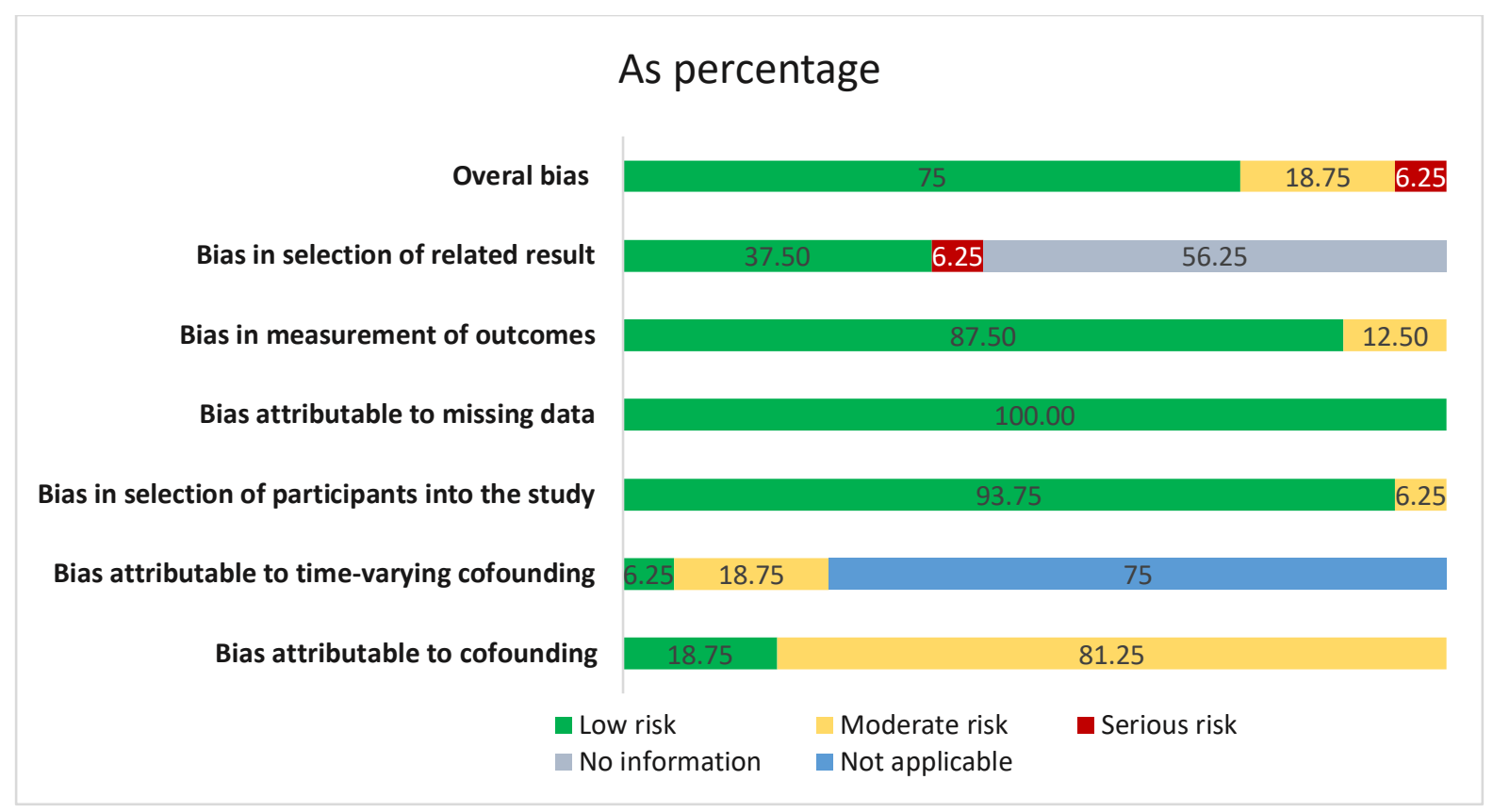

Figure 4. Study-level risk of bias: based on WIB, ROBIN-I, and AXIS items combined into six categories proposed by Page et al., 2018 with an addition of the confounding bias described in ROBIN-I. 


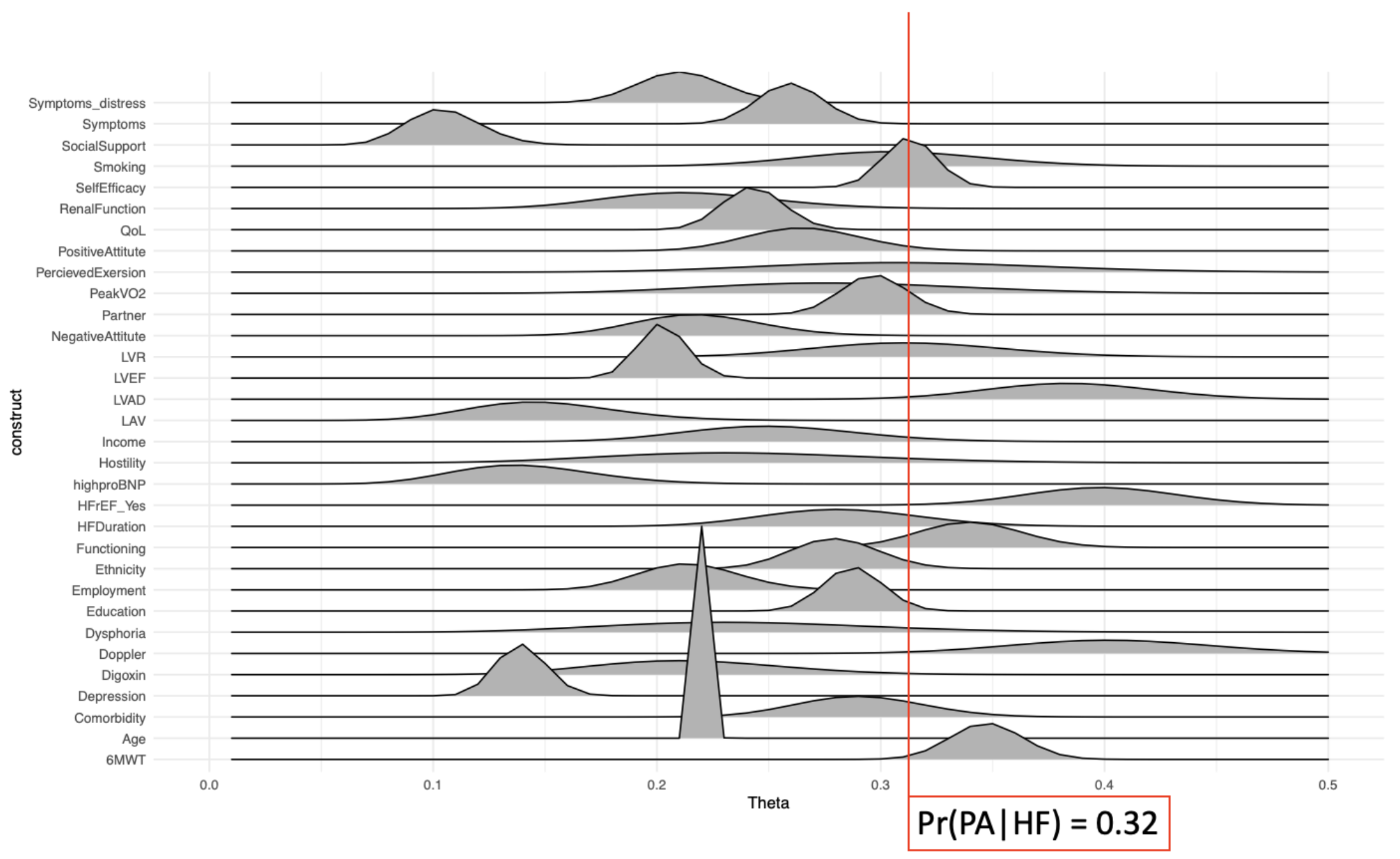

Figure 5. Bayesian updating: the posterior probability distribution for physical activity conditioned on identified determinants as suggested by the quantitative evidence (quant). 


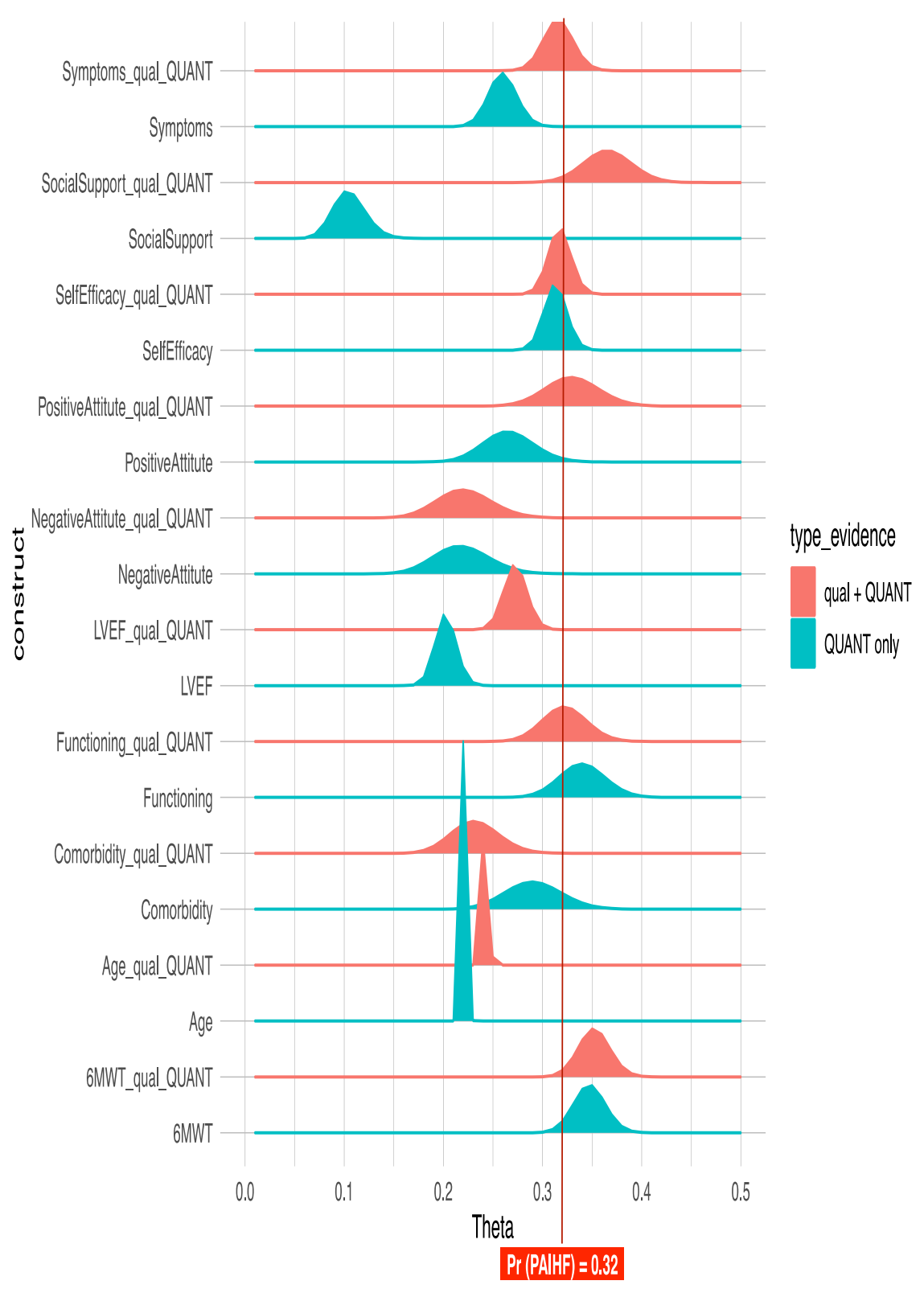


Figure 6. Bayesian updating: the posterior probability distribution for physical activity conditioned on identified determinants according to qualitative combined with quantitative evidence (QUAL + quant) and according to quantitative evidence alone (quant). 